\title{
Five new 2-(2-phenylethyl)chromone derivatives and three new sesquiterpenoids from the heartwood of Aquilaria sinensis, an aromatic medicine in China
}

Lu Zhang ${ }^{1 \dagger}$, Ping Yi ${ }^{2+}$, Hui Yan ${ }^{1}$, Xiao-Nian Li ${ }^{1}$, Meng-Yuan Xia ${ }^{1}$, Jun Yang ${ }^{1}$, Ji-Feng Luo ${ }^{1}$, Yue-Qiu He ${ }^{3^{*}}$ and Yue-Hu Wang ${ }^{1 *}$ (i)

\begin{abstract}
Five new 2-(2-phenylethyl)chromone derivatives, (5S,6R,7R,8S,7'R)-7'-hydroxyagarotetrol (1), $\left(5 S, 6 R, 7 R, 8 S, 7^{\prime} S\right)-7^{\prime}$ hydroxyagarotetrol (2), (6S,75,8R)-2-[2-(4-methoxyphenyl)ethyl]-6,7,8-trihydroxy-5,6,7,8-tetrahydrochromone (3), $(6 S, 75,8 R)-2$-(2-phenylethyl)-6,7,8-trihydroxy-5,6,7,8-tetrahydrochromone (4), (5S,6R,7S,8R)-2-(2-phenylethyl)-5,6,7-trihydroxy-5,6,7,8-tetrahydro-8-[2-(2-phenylethyl)-7-methoxychromonyl-6-oxy]chromone (5), three new sesquiterpenoids, (4S,5S,7S,8S, 10S,13R)-7,8,13-trihydroxyrotunda-1,11-dien-3-one (6), (4S,5S,7S,8S, 10S,13S)-7,8,13-trihydroxyrotunda1,11-dien-3-one (7), and (4R,5S,7S,8S,10S,13S)-7,8,13-trihydroxyrotunda-1,11-dien-3-one (8), along with 14 known compounds were isolated from the resinous heartwood of Aquilaria sinensis (Thymelaeaceae). The chemical structures of these new compounds were elucidated by 1D and 2D NMR and MS data, single-crystal X-ray diffraction analysis, and electronic circular dichroism (ECD) calculations. The neuroprotective activities of these isolates were evaluated using an in vitro model of rat adrenal pheochromocytoma (PC12) cell injury induced by corticosterone. At concentrations from 5 to $40 \mu \mathrm{M}$, compounds $\mathbf{4}$ and 6, agarotetrol (9), and 6-hydroxy-2-(2-phenylethyl)chromone (17) showed significant protective activities against corticosterone-induced $P C 12$ cell injury $(P<0.001)$.
\end{abstract}

Keywords: Thymelaeaceae, Aquilaria sinensis, Sesquiterpenoids, 2-(2-Phenylethyl)chromones, Neuroprotective

\footnotetext{
*Correspondence: ynfh2007@163.com; wangyuehu@mail.kib.ac.cn

† Lu Zhang and Ping Yi contributed equally to this work

1 Key Laboratory of Economic Plants and Biotechnology, Yunnan

Key Laboratory for Wild Plant Resources, and State Key Laboratory

of Phytochemistry and Plant Resources in West China, Kunming Institute

of Botany, Chinese Academy of Sciences, Kunming 650201, People's

Republic of China

${ }^{3}$ Faculty of Plant Protection, Yunnan Agricultural University,

Kunming 650201, People's Republic of China

Full list of author information is available at the end of the article
} original author(s) and the source, provide a link to the Creative Commons licence, and indicate if changes were made. The images or other third party material in this article are included in the article's Creative Commons licence, unless indicated otherwise in a credit line to the material. If material is not included in the article's Creative Commons licence and your intended use is not permitted by statutory regulation or exceeds the permitted use, you will need to obtain permission directly from the copyright holder. To view a copy of this licence, visit http://creativecommons.org/licenses/by/4.0/. 


\section{Graphical Abstract}

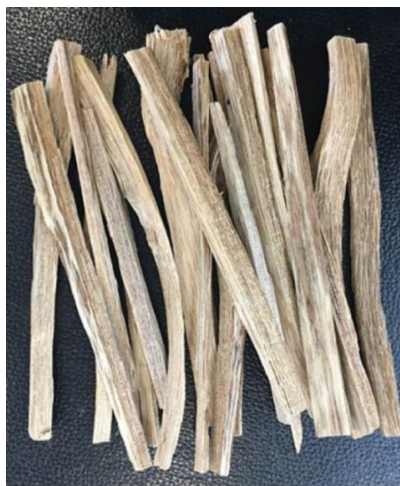<smiles>CC1C(C)C(C)C(C(C)(C)C2CC3C(C)C(C)C(C)(C)C3CC2(C)C)C(C)C1C</smiles>

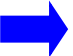<smiles>COc1ccc(CCc2cc(=O)c3c(o2)[C@@H](O)[C@@H](O)[C@@H](O)C3)cc1</smiles><smiles>CC1C(C)C(C)C2(C)C(C)C(C)C(C(C)(C)C3C(C)C(C)C(CC(C)(C)C)C(C)C3C)CC2C1C</smiles>

\section{Introduction}

Chen-xiang (Aquilariae Lignum Resinatum), resinous heartwoods of the Thymelaeaceous plant Aquilaria sinensis (Lour.) Spreng., is one of the most well-known aromatic medicines in China [1, 2]. More than 240 compounds, mainly sesquiterpenoids, diterpenoids, steroids, benzyl acetones, chromones, phenolic acids, and aliphatic compounds, have been found in chenxiang. Some compounds showed antibacterial, anticancer, acetylcholinesterase inhibitory, and other pharmacological activities [3]. Aromatic plants are thought to be a source of chemical constituents with neuroprotective effects [4]. In our continuing efforts to search for neuroprotective compounds from chenxiang [5, 6], five new 2-(2-phenylethyl)chromone derivatives (1-5, Fig. 1) and three new sesquiterpenoids (6-8, Fig. 1), along with 14 known compounds (9-22, Additional file 1: Fig. S1), were isolated. In the present paper, structural elucidation of these new compounds and bioassay results for the neuroprotective activity of these isolates are reported.<smiles>[R]C(=O)O</smiles><smiles>[R][R]#[R][H]</smiles><smiles>COc1cc2oc(CCc3ccccc3)cc(=O)c2cc1O[C@H]1c2oc(C[C]c3ccccc3)cc(=O)c2[C@H](O)[C@H](O)[C@H]1O</smiles>

Fig. 1 Chemical structures of compounds 1-8 from Aquilaria sinensis

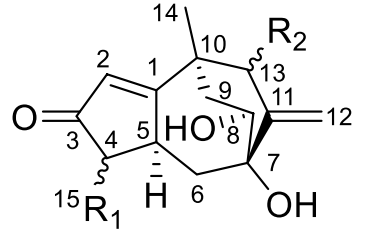

$6 \mathrm{R}_{1}=\alpha-\mathrm{Me} \mathrm{R}_{2}=\beta-\mathrm{OH}$

$7 \mathrm{R}_{1}=\alpha-\mathrm{Me} \mathrm{R} \mathrm{R}_{2}=\alpha-\mathrm{OH}$

$8 \mathrm{R}_{1}=\beta-\mathrm{Me}, \mathrm{R}_{2}=\alpha-\mathrm{OH}$ 
Table $1{ }^{1} \mathrm{H}(500 \mathrm{MHz})$ and ${ }^{13} \mathrm{C}(126 \mathrm{MHz})$ NMR data of $\mathbf{1}$ and $\mathbf{2}$ in methanol- $d_{4}(\delta$ in ppm, $J$ in $\mathrm{Hz})$

\begin{tabular}{|c|c|c|c|c|}
\hline \multirow[t]{2}{*}{ No } & \multicolumn{2}{|l|}{1} & \multicolumn{2}{|l|}{2} \\
\hline & $\delta_{\mathrm{H}}$ & $\delta_{\mathrm{C}}$ & $\delta_{\mathrm{H}}$ & $\delta_{\mathrm{C}}$ \\
\hline 2 & & 169.1 & & 169.2 \\
\hline 3 & $6.19(\mathrm{~s})$ & 115.5 & $6.22(\mathrm{~s})$ & 115.5 \\
\hline 4 & & 181.9 & & 181.9 \\
\hline $4 a$ & & 121.8 & & 121.9 \\
\hline 5 & $4.75(d, 4.0)$ & 66.7 & $4.75(d, 4.0)$ & 66.7 \\
\hline 6 & $4.02(\mathrm{dd}, 4.0,2.4)$ & 74.0 & $4.02(\mathrm{dd}, 4.0,2.3)$ & 74.0 \\
\hline 7 & $4.04(\mathrm{dd}, 7.5,2.4)$ & 72.4 & $4.04(\mathrm{dd}, 7.5,2.3)$ & 72.4 \\
\hline 8 & $4.56(d, 7.5)$ & 70.1 & $4.56(d, 7.5)$ & 70.1 \\
\hline $8 a$ & & 165.4 & & 165.4 \\
\hline $1^{\prime}$ & & 144.8 & & 145.0 \\
\hline $2^{\prime}, 6^{\prime}$ & $7.41(\mathrm{~m})$ & 126.9 & $7.41(\mathrm{~m})$ & 126.9 \\
\hline $3^{\prime}, 5^{\prime}$ & $7.34(\mathrm{~m})$ & 129.5 & $7.35(\mathrm{~m})$ & 129.5 \\
\hline $4^{\prime}$ & $7.26(\mathrm{~m})$ & 128.8 & $7.27(\mathrm{~m})$ & 128.8 \\
\hline $7^{\prime}$ & $5.10(\mathrm{dd}, 8.0,5.8)$ & 72.4 & $5.11(\mathrm{dd}, 8.0,5.4)$ & 72.3 \\
\hline $\begin{array}{l}8^{\prime} a \\
8^{\prime} \beta\end{array}$ & $\begin{array}{l}3.01(\mathrm{dd}, 14.6,8.0) \\
2.97(\mathrm{dd}, 14.6,5.8)\end{array}$ & 44.4 & $\begin{array}{l}3.00(\mathrm{dd}, 14.6,5.4) \\
2.96(\mathrm{dd}, 14.6,8.0)\end{array}$ & 44.4 \\
\hline
\end{tabular}

\section{Results and discussion}

\subsection{Structure elucidation}

Compound 1 was obtained as colorless needles (MeOH). Based on the HRESIMS at $\mathrm{m} / z 357.0942[\mathrm{M}+\mathrm{Na}]^{+}$ (calcd for $\mathrm{C}_{17} \mathrm{H}_{18} \mathrm{NaO}_{7}, 357.0950$ ) and ${ }^{13} \mathrm{C}$ NMR data (Table 1), its molecular formula was deduced to be $\mathrm{C}_{17} \mathrm{H}_{18} \mathrm{O}_{7}$ with nine indices of hydrogen deficiency. Its IR spectrum indicated the presence of hydroxy groups $\left(3406 \mathrm{~cm}^{-1}\right)$, an $\alpha, \beta$-unsaturated carbonyl $\left(1658 \mathrm{~cm}^{-1}\right)$, and a monosubstituted phenyl ring (1601, 1448, and $\left.701 \mathrm{~cm}^{-1}\right)$. According to the ${ }^{1} \mathrm{H}$ NMR data of compound 1 (Table 1), a trisubstituted double bond $\left[\delta_{\mathrm{H}} 6.19(1 \mathrm{H}\right.$, s)] and a monosubstituted phenyl ring $\left[\delta_{\mathrm{H}} 7.26-7.41\right.$ $(5 \mathrm{H}, \mathrm{m})]$ were deduced. Its NMR data (Table 1) were very similar to those of agarotetrol $(9)[7,8]$, a common 2-(2-phenylethyl)-5,6,7,8-tetrahydrochromone found in Aquilaria plants. The main difference was that signals for a methylene in agarotetrol were replaced by signals $\left[\delta_{\mathrm{H}} 5.10(\mathrm{dd}, J=8.0,5.8 \mathrm{~Hz}) ; \delta_{\mathrm{C}} 72.4\right]$ for an oxygenated methine in compound $\mathbf{1}$.

Based on the ${ }^{1} \mathrm{H}-{ }^{1} \mathrm{H}$ COSY correlations of 1 (Fig. 2), fragments of $\mathrm{C}-5$ to $\mathrm{C}-8, \mathrm{C}-2^{\prime}$ to $\mathrm{C}-6^{\prime}$, and $\mathrm{C}-7^{\prime}$ to $\mathrm{C}-8^{\prime}$
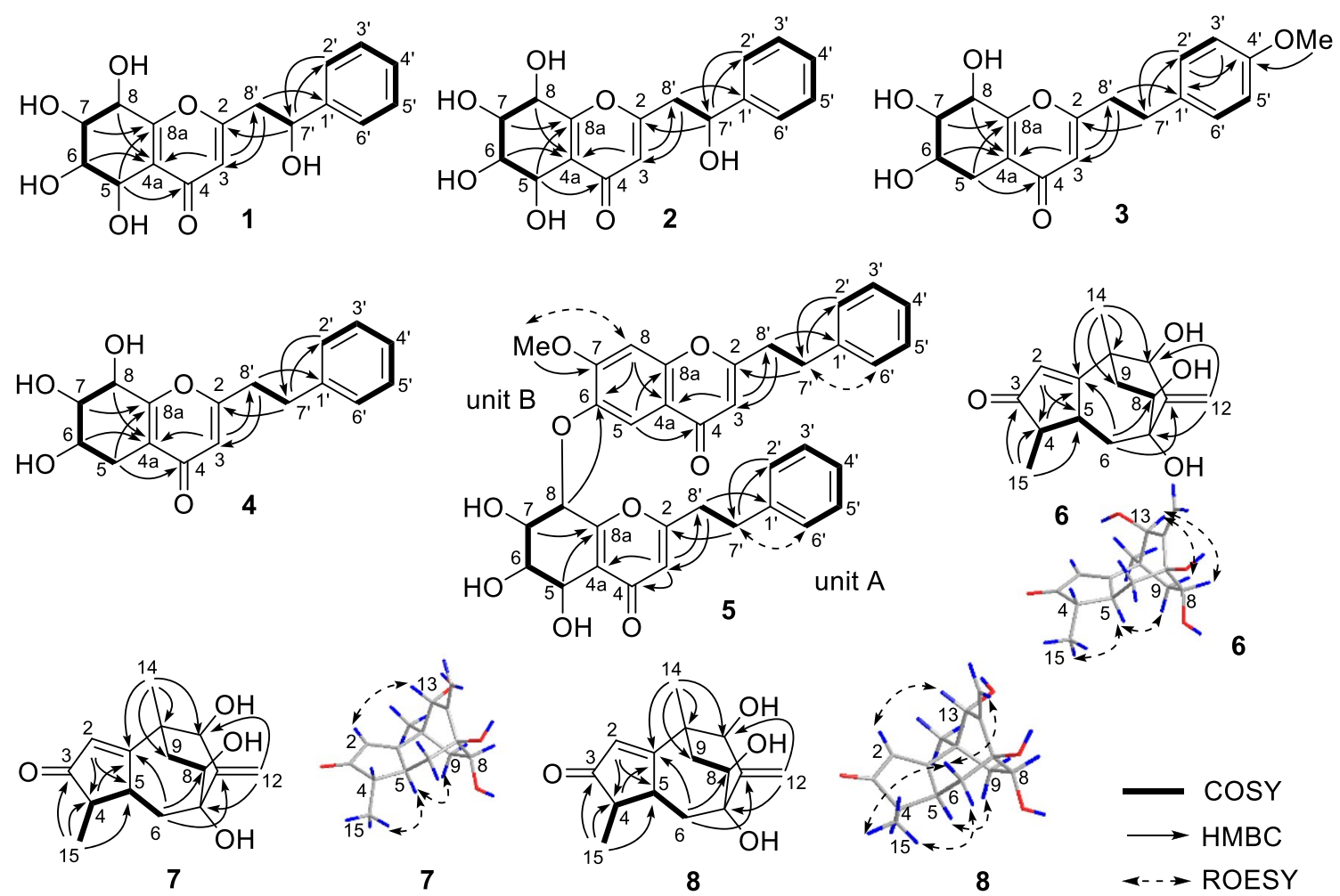

Fig. 2 Key 2D NMR correlations of compounds $\mathbf{1 - 8}$ 
were deduced. $\mathrm{HMBC}$ correlations (Fig. 2) from $\delta_{\mathrm{H}} 7.41$ $\left(\mathrm{H}-2^{\prime}, \mathrm{H}-6^{\prime}\right)$ to $\delta_{\mathrm{C}} 72.3\left(\mathrm{C}-7^{\prime}\right)$ and from $\delta_{\mathrm{H}} 2.97\left(\mathrm{H}-8^{\prime} \beta\right)$ to $\delta_{\mathrm{C}} 144.8\left(\mathrm{C}-1^{\prime}\right)$ indicated the presence of a 2-hydroxy2-phenylethyl fragment in 1. HMBC correlations from $\delta_{\mathrm{H}} 2.97\left(\mathrm{H}-8^{\prime} \beta\right)$ to $\delta_{\mathrm{C}} 115.5(\mathrm{C}-3)$, from $\delta_{\mathrm{H}} 6.19(\mathrm{H}-3)$ to $\delta_{\mathrm{C}} 44.4\left(\mathrm{C}-8^{\prime}\right)$, and from $\delta_{\mathrm{H}} 5.11(\mathrm{H}-7)$ to $\delta_{\mathrm{C}} 169.1(\mathrm{C}-2)$ implied that the 2-hydroxy-2-phenylethyl fragment was located at C-2. $\mathrm{HMBC}$ correlations from $\delta_{\mathrm{H}} 4.75(\mathrm{H}-5)$ to $\delta_{\mathrm{C}} 181.9(\mathrm{C}-4)$ and $\delta_{\mathrm{C}} 165.4(\mathrm{C}-8 \mathrm{a})$, from $\delta_{\mathrm{H}} 4.56(\mathrm{H}-8)$ to $\delta_{\mathrm{C}} 121.8(\mathrm{C}-4 \mathrm{a})$, and from $\delta_{\mathrm{H}} 6.19(\mathrm{H}-3)$ to $\delta_{\mathrm{C}} 121.8$ (C-4a), a planar structure 2-(2-phenylethyl)-5,6,7,8,7'-pe ntahydroxy-5,6,7,8-tetrahydrochromone was deduced.

It is difficult to determine the relative configuration of 5,6,7,8-tetrahydroxy-5,6,7,8-tetrahydrochromones by ROESY correlations, while the coupling constants of H-5 to H-8 are helpful. $J_{5,6}(4.0 \mathrm{~Hz}), J_{6,7}(2.4 \mathrm{~Hz})$, and $J_{7,8}(7.5 \mathrm{~Hz})$ values of compound $\mathbf{1}$ were close to those of $5 \alpha, 6 \beta, 7 \beta, 8 \alpha$-tetrahydroxy-5,6,7,8-tetrahydrochromone analogs [9], implying the $5 \alpha, 6 \beta, 7 \beta, 8 \alpha$-tetrahydroxy configuration in 1 . The relative configuration of $\mathrm{H}-\mathrm{7}^{\prime}$ was also determined by comparing its coupling constant with that of known compounds. In isomers $\left(5 S, 6 R, 7 S, 8 R, 7^{\prime} R\right)-7^{\prime}-$ hydroxyisoagarotetrol (15) [10] and $\left(5 S, 6 R, 7 S, 8 R, 7^{\prime} S\right)-7^{\prime}-$ hydroxyisoagarotetrol (16) [10], the main differences in ${ }^{1} \mathrm{H}$ NMR spectra were $J_{7^{\prime}, 8^{\prime}}$ values. Because $J_{7^{\prime}, 8^{\prime} \alpha}(8.0 \mathrm{~Hz})$ and $J_{7^{\prime}, 8^{\prime} \beta}(5.8 \mathrm{~Hz})$ values of compound 1 were close to those of the $7^{\prime} \alpha-\mathrm{OH}$ isomer $\left(15 ; J_{7^{\prime}, 8^{\prime} \alpha}=8.0 \mathrm{~Hz}\right.$ and $J_{7^{\prime}, 8^{\prime} \beta}=5.5 \mathrm{~Hz}$ ), $7^{\prime}-\mathrm{OH}$ of $\mathbf{1}$ was deduced to be $\alpha$-oriented. The absolute configuration of $\mathbf{1}$ was determined to be $\left(5 S, 6 R, 7 R, 8 S, 7^{\prime} R\right)-7^{\prime}$-hydroxyagarotetrol (Fig. 3) by singlecrystal X-ray diffraction using graphite monochromated $\mathrm{CuK} \alpha$ radiation with a Flack parameter of 0.11 (10).

The molecular formula of 2 was deduced to be the same as that of compound $\mathbf{1}, \mathrm{C}_{17} \mathrm{H}_{18} \mathrm{O}_{7}$, by ${ }^{13} \mathrm{C}$ NMR (Table 1) and HRESIMS at $\mathrm{m} / z \quad 357.0945$
$[\mathrm{M}+\mathrm{Na}]^{+} \quad$ (calcd for $\mathrm{C}_{17} \mathrm{H}_{18} \mathrm{NaO}_{7}$, 357.0950). Detailed comparison of its NMR data with those of $\quad\left(5 S, 6 R, 7 S, 8 R, 7^{\prime} R\right)-7^{\prime}$-hydroxyisoagarotetrol (1), $\left(5 S, 6 R, 7 S, 8 R, 7^{\prime} R\right)-7^{\prime}$-hydroxyisoagarotetrol (15), and $\left(5 S, 6 R, 7 S, 8 R, 7^{\prime} S\right)-7^{\prime}$-hydroxyisoagarotetrol (16) [10], compound 2 was elucidated to be 7 '-epimer of $\mathbf{1}$, which was confirmed by 2D NMR correlations of 2 (Fig. 2). Because $J_{7^{\prime}, 8^{\prime} \alpha}(5.4 \mathrm{~Hz})$ and $J_{7^{\prime}, 8^{\prime} \beta}(8.0 \mathrm{~Hz})$ values of compound 2 were close to those of the $7^{\prime} \beta-\mathrm{OH}$ isomer (16; $J_{7^{\prime}, 8^{\prime} \alpha}=5.0 \mathrm{~Hz}$ and $J_{7^{\prime}, 8^{\prime} \beta}=8.5 \mathrm{~Hz}$ ) [10], the $7^{\prime}-\mathrm{OH}$ of 2 was deduced to be $\beta$-oriented. Thus, compound 2 was elucidated to be $\left(5 S, 6 R, 7 S, 8 R, 7^{\prime} S\right)-7^{\prime}$-hydroxyisoagarotetrol.

Compound 3 had the molecular formula $\mathrm{C}_{18} \mathrm{H}_{20} \mathrm{O}_{6}$ based on ${ }^{13} \mathrm{C}$ NMR data (Table 2) and the positive ion at $\mathrm{m} / z 355.1150[\mathrm{M}+\mathrm{Na}]^{+}$(calcd for $\mathrm{C}_{18} \mathrm{H}_{20} \mathrm{NaO}_{6}$, $355.1158)$ in the HRESIMS. The ${ }^{1} \mathrm{H}$ and ${ }^{13} \mathrm{C}$ NMR spectra showed resonances for one $p$-disubstituted phenyl ring $\left[\delta_{\mathrm{H}} 7.12(2 \mathrm{H}, \mathrm{br} \mathrm{d}, J=8.6 \mathrm{~Hz})\right.$ and $6.82(2 \mathrm{H}, \mathrm{br}$ d, $J=8.6 \mathrm{~Hz}) ; \delta_{\mathrm{C}} 159.8,133.2,130.4 \times 2$, and $115.0 \times 2$ ], one trisubstituted $4 H$-pyran-4-one $\left[\delta_{\mathrm{H}} 6.07(\mathrm{~s}) ; \delta_{\mathrm{C}} 182.0\right.$, $171.2,163.0,120.9$, and 113.1], one methoxy group $\left[\delta_{\mathrm{H}}\right.$ $\left.3.75(3 \mathrm{H}, \mathrm{s}) ; \delta_{\mathrm{C}} 55.6\right]$, three $s p^{3}$ methylenes $\left(\delta_{\mathrm{C}} 36.6\right.$, 33.0, and 26.5), and three oxygenated methine $\left[\delta_{\mathrm{H}} 4.50\right.$ $(\mathrm{d}, J=5.0 \mathrm{~Hz}$ ), 4.11 (ddd, $J=7.4,5.1,2.2 \mathrm{~Hz}$ ), and 3.90 (dd, $J=5.0,2.2 \mathrm{~Hz}$ ); $\delta_{\mathrm{C}} 75.0,71.2$, and 67.3], implying that it might also be a 5,6,7,8-tetrahydrochromone with the substituted mode of three hydroxy groups at ring $B$ rather than the usual mode of four hydroxy groups at ring B. Four fragments, $\mathrm{C}-5$ to $\mathrm{C}-8, \mathrm{C}-2^{\prime}$ to $\mathrm{C}-3^{\prime}$, $\mathrm{C}-5^{\prime}$ to $\mathrm{C}-6^{\prime}$, and $\mathrm{C}-7^{\prime}$ to $\mathrm{C}-8^{\prime}$, were deduced by ${ }^{1} \mathrm{H}-{ }^{1} \mathrm{H}$ COSY correlations (Fig. 2). Its planar structure was deduced to be 2-[2-(4-methoxyphenyl)ethyl]-6,7,8-trihydroxy-5,6,7,8-tetrahydrochromone by key HMBC correlations (Fig. 2) from $\mathrm{H}-3$ to $\mathrm{C}-4 \mathrm{a}$ and $\mathrm{C}-8^{\prime}$, from $\mathrm{H}-5$ to C-4 and C-8a, from H-6 and H-8 to C-4a, from $\mathrm{H}-7$ to
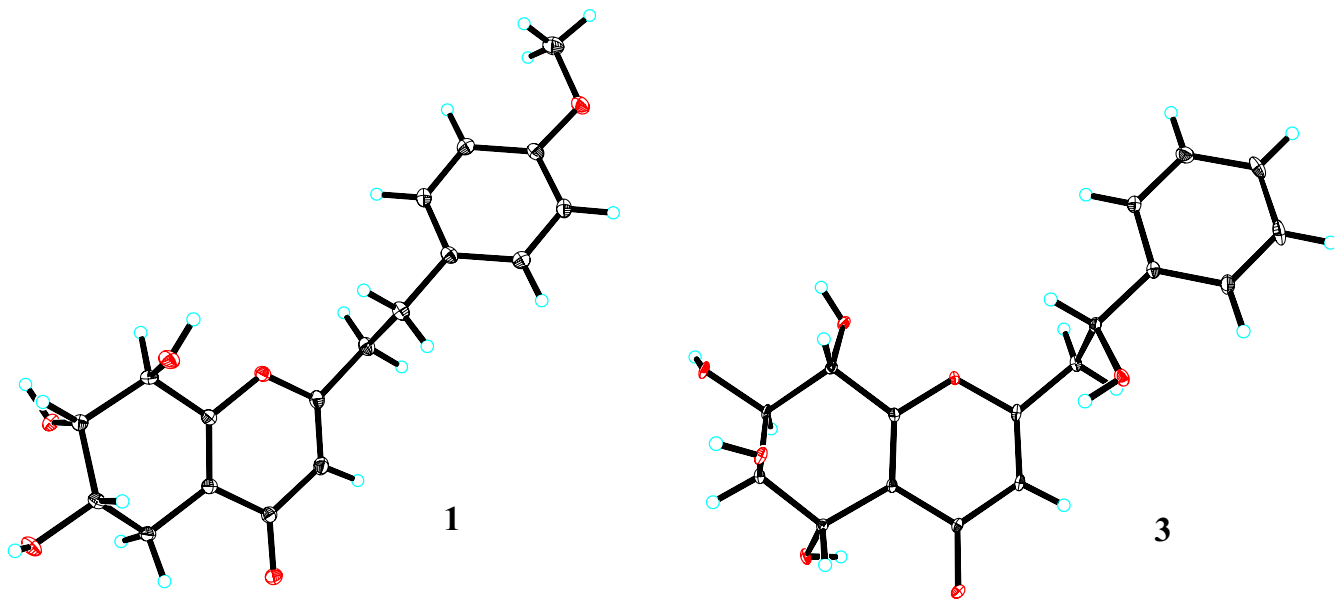

Fig. 3 X-ray crystallographic structures of $\mathbf{1}$ and $\mathbf{3}$ 
Table $2{ }^{1} \mathrm{H}$ and ${ }^{13} \mathrm{C}$ NMR data of $\mathbf{3}$ and $\mathbf{4}$ in methanol- $d_{4}(\delta$ in ppm, $J$ in $\mathrm{Hz})$

\begin{tabular}{|c|c|c|c|c|}
\hline \multirow[t]{2}{*}{ No } & \multicolumn{2}{|l|}{3} & \multicolumn{2}{|l|}{4} \\
\hline & $\delta_{\mathrm{H}}(600 \mathrm{MHz})$ & $\delta_{\mathrm{C}}(151 \mathrm{MHz})$ & $\delta_{\mathrm{H}}(500 \mathrm{MHz})$ & $\delta_{\mathrm{C}}(126 \mathrm{MHz})$ \\
\hline 2 & & 171.2 & & 171.1 \\
\hline 3 & $6.07(s)$ & 113.1 & $6.09(\mathrm{~s})$ & 113.0 \\
\hline 4 & & 182.0 & & 181.9 \\
\hline $4 a$ & & 120.9 & & 120.9 \\
\hline $\begin{array}{l}5 \beta \\
5 a\end{array}$ & $\begin{array}{l}2.66(\mathrm{dd}, 16.9,5.1) \\
2.51(\mathrm{dd}, 16.9,7.4)\end{array}$ & 26.5 & $\begin{array}{l}2.67(\mathrm{dd}, 17.2,5.0) \\
2.51(\mathrm{dd}, 17.2,7.5)\end{array}$ & 26.5 \\
\hline 6 & $4.11(\mathrm{ddd}, 7.4,5.1,2.2)$ & 67.3 & $4.11(\mathrm{ddd}, 7.5,5.0,2.1)$ & 67.3 \\
\hline 7 & $3.90(\mathrm{dd}, 5.0,2.2)$ & 75.0 & $3.90(\mathrm{dd}, 5.0,2.1)$ & 75.0 \\
\hline 8 & $4.50(d, 5.0)$ & 71.2 & $4.50(d, 5.0)$ & 71.2 \\
\hline $8 a$ & & 163.0 & & 163.0 \\
\hline $1^{\prime}$ & & 133.2 & & 141.2 \\
\hline $2^{\prime}, 6^{\prime}$ & $7.12(\mathrm{br} \mathrm{d}, 8.6)$ & 130.4 & $7.26(\mathrm{~m})$ & 129.6 \\
\hline $3^{\prime}, 5^{\prime}$ & $6.82(\mathrm{br} \mathrm{d}, 8.6)$ & 115.0 & $7.22(\mathrm{~m})$ & 129.5 \\
\hline $4^{\prime}$ & & 159.8 & $7.18(\mathrm{~m})$ & 127.4 \\
\hline $7^{\prime}$ & $2.96(\mathrm{~m})$ & 33.0 & $3.02(\mathrm{~m})$ & 33.8 \\
\hline $8^{\prime}$ & $2.89(\mathrm{~m})$ & 36.6 & $2.92(\mathrm{~m})$ & 36.3 \\
\hline 4'-OMe & $3.75(\mathrm{~s})$ & 55.6 & & \\
\hline
\end{tabular}

C-8a, from $\mathrm{H}-2^{\prime}$ and $\mathrm{H}-6^{\prime}$ to $\mathrm{C}-7^{\prime}, \mathrm{H}-3^{\prime}$ and $\mathrm{H}-5^{\prime}$ to $\mathrm{C}-1^{\prime}$, $4^{\prime}-\mathrm{OMe}$ to $\mathrm{C}-4^{\prime}, \mathrm{H}_{2}-7^{\prime}$ to $\mathrm{C}-2, \mathrm{C}-2^{\prime}$, and $\mathrm{C}-6^{\prime}$, and $\mathrm{H}_{2}-8^{\prime}$ to $\mathrm{C}-1^{\prime}$ and $\mathrm{C}-3$. Finally, the absolute configuration of $\mathbf{3}$ was determined to be $(6 S, 7 S, 8 R)$-2-[2-(4-methoxyphenyl)ethyl]-6,7,8-trihydroxy-5,6,7,8-tetrahydrochromone (Fig. 3) by single-crystal X-ray diffraction using graphite monochromated $\mathrm{CuK} \alpha$ radiation with a Flack parameter of 0.09 (4).

Compound 4 was assigned the molecular formula $\mathrm{C}_{17} \mathrm{H}_{18} \mathrm{O}_{5}$ based on ${ }^{13} \mathrm{C}$ NMR data (Table 2) and the positive ion at $m / z 325.1046[\mathrm{M}+\mathrm{Na}]^{+}$(calcd for $\left.\mathrm{C}_{17} \mathrm{H}_{18} \mathrm{NaO}_{5}, 325.1052\right)$ in the HRESIMS. By extensively comparing the NMR data (Table 2) of compounds 3 and $\mathbf{4}$, signals for one monosubstituted phenyl ring were found in $\mathbf{4}$ rather than the disubstituted phenyl ring in 3, and signals for a methoxy group disappeared in 4. Otherwise, the NMR data of these two compounds were very close to each other, implying that compound 4 is the $4^{\prime}$-demethoxy derivative of $\mathbf{3}$, which was confirmed by the ${ }^{1} \mathrm{H}-{ }^{1} \mathrm{H}$ COSY and HMBC correlations of 4 (Fig. 2). The chemical shifts and coupling constants of H-6 [ $\delta_{\mathrm{H}} 4.11$ (ddd, $J=7.5,5.0,2.1 \mathrm{~Hz}$ )], $\mathrm{H}-7\left[\delta_{\mathrm{H}} 3.90(\mathrm{dd}, J=5.0,2.1 \mathrm{~Hz})\right]$, and H-8 $\left[\delta_{\mathrm{H}} 4.50(\mathrm{~d}\right.$, $J=5.0 \mathrm{~Hz}$ )] of compound 4 were very close to those of H-6 $\left[\delta_{\mathrm{H}} 4.11\right.$ (ddd, $J=7.4,5.1,2.2 \mathrm{~Hz}$ )], H-7 $\left[\delta_{\mathrm{H}} 3.90\right.$ $(\mathrm{dd}, J=5.0,2.2 \mathrm{~Hz})]$, and $\mathrm{H}-8\left[\delta_{\mathrm{H}} 4.50(\mathrm{~d}, J=5.0 \mathrm{~Hz})\right]$ of compound 3, implying $6 \alpha-\mathrm{OH}, 7 \alpha-\mathrm{OH}$, and $8 \beta-\mathrm{OH}$ configurations in $\mathbf{4}$. The absolute configuration of $\mathbf{4}$ was

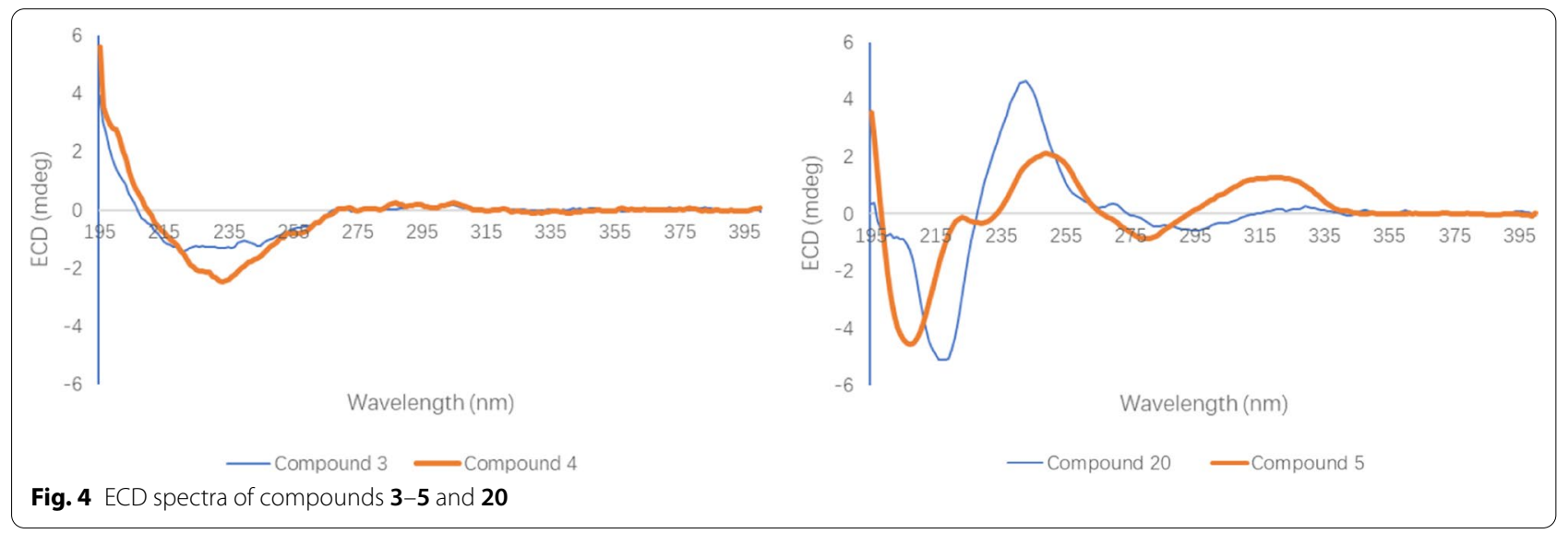


Table $3{ }^{1} \mathrm{H}(600 \mathrm{MHz})$ and ${ }^{13} \mathrm{C}(151 \mathrm{MHz})$ NMR data of $\mathbf{5}$ in methanol- $d_{4}(\delta$ in ppm, $J$ in $\mathrm{Hz})$

\begin{tabular}{|c|c|c|}
\hline No & $\delta_{\mathrm{H}}$ & $\delta_{\mathrm{C}}$ \\
\hline \multicolumn{3}{|l|}{ Unit A } \\
\hline 2 & & 171.2 \\
\hline 3 & $6.13(\mathrm{~s})$ & 114.4 \\
\hline 4 & & 182.0 \\
\hline $4 a$ & & 122.5 \\
\hline 5 & $4.75(\mathrm{dd}, 6.9,1.3)$ & 70.3 \\
\hline 6 & $3.83(d d, 9.6,6.9)$ & 74.9 \\
\hline 7 & $4.00(\mathrm{dd}, 9.6,7.3)$ & 73.6 \\
\hline 8 & $5.45(\mathrm{dd}, 7.3,1.3)$ & 79.5 \\
\hline $8 a$ & & 160.7 \\
\hline $1^{\prime}$ & & 140.9 \\
\hline $2^{\prime}, 6^{\prime}$ & $6.95(m)$ & 129.2 \\
\hline $3^{\prime}, 5^{\prime}$ & $7.16(m)$ & 129.5 \\
\hline $4^{\prime}$ & $7.11(\mathrm{~m})$ & 127.4 \\
\hline $7^{\prime}$ & $2.62(\mathrm{~m})$ & 33.4 \\
\hline $8^{\prime}$ & $\begin{array}{l}2.75(\mathrm{~m}) \\
2.65(\mathrm{~m})\end{array}$ & 36.2 \\
\hline \multicolumn{3}{|l|}{ Unit B } \\
\hline 2 & & 170.9 \\
\hline 3 & $6.11(\mathrm{~s})$ & 110.1 \\
\hline 4 & & 179.7 \\
\hline $4 a$ & & 117.4 \\
\hline 5 & 7.90 (s) & 110.4 \\
\hline 6 & & 148.8 \\
\hline 7 & & 157.3 \\
\hline 8 & $7.22(\mathrm{~s})$ & 101.7 \\
\hline $8 a$ & & 155.0 \\
\hline $1^{\prime}$ & & 141.3 \\
\hline $2^{\prime}, 6^{\prime}$ & $7.22(\mathrm{~m})$ & 129.5 \\
\hline $3^{\prime}, 5^{\prime}$ & $7.24(\mathrm{~m})$ & 129.6 \\
\hline $4^{\prime}$ & $7.17(\mathrm{~m})$ & 127.5 \\
\hline $7^{\prime}$ & $3.08(t, 7.5)$ & 34.1 \\
\hline $8^{\prime}$ & $3.02(t, 7.5)$ & 37.0 \\
\hline 7-OMe & $3.98(s)$ & 57.2 \\
\hline
\end{tabular}

suggested to be $(6 S, 7 S, 8 R)$-2-(2-phenylethyl)-6,7,8-trihydroxy-5,6,7,8-tetrahydrochromone in view of its ECD spectrum similar to that of compound 3 (Fig. 4).

A molecular formula, $\mathrm{C}_{35} \mathrm{H}_{32} \mathrm{O}_{9}$, was assigned to compound 5 by positive HRESIMS with an ion at $m / z$ $619.1939[\mathrm{M}+\mathrm{Na}]^{+}\left(\right.$calcd $\left.\mathrm{C}_{35} \mathrm{H}_{32} \mathrm{NaO}_{9}, 619.1944\right)$ and ${ }^{13} \mathrm{C}$ NMR data (Table 3). According to its NMR data (Table 3), signals for two sets of phenylethyl moieties $\left(\delta_{\mathrm{C}}\right.$ $141.3,140.9,129.2 \times 2,129.6 \times 2,129.5 \times 4,127.5,127.4$, $37.0,36.2,34.1$, and 33.4), one 5,6,7,8-tretrahydroxy$5,6,7,8$-tetrahydrochromone moiety $\left[\delta_{\mathrm{H}} 6.13(\mathrm{~s}), 5.45\right.$ $(\mathrm{dd}, J=7.3,1.3 \mathrm{~Hz}), 4.75(\mathrm{dd}, J=6.9,1.3 \mathrm{~Hz}), 4.00(\mathrm{dd}$, $J=9.6,7.3 \mathrm{~Hz}$ ), and $3.83(\mathrm{dd}, J=9.6,6.9 \mathrm{~Hz}) ; \delta_{\mathrm{C}} 182.0$, $171.2,160.7,122.5,114.4,79.5,74.9,73.6$, and 70.3], one trisubstituted chromone $\left[\delta_{\mathrm{H}} 7.90(\mathrm{~s}), 7.22(\mathrm{~s})\right.$, and $6.11(\mathrm{~s}) ; \delta_{\mathrm{C}} 179.7,170.9,157.3,155.0,148.8,117.4,110.4$, 110.1 , and 101.7], and one methoxy group [ $\delta_{\mathrm{H}} 3.98(\mathrm{~s}) ; \delta_{\mathrm{C}}$ 57.2], were observed, which implied that this compound might be a dimer of a 2-(2-phenylethyl)chromone and a 5,6,7,8-tretrahydroxy-5,6,7,8-tetrahydro-2-(2-phenylethyl)chromone. In unit A of 5 (Fig. 2), three ${ }^{1} \mathrm{H}-{ }^{1} \mathrm{H}$ COSY fragments, $\mathrm{H}-5 / \mathrm{H}-6 / \mathrm{H}-7 / \mathrm{H}-8, \mathrm{H}-2^{\prime} / \mathrm{H}-3^{\prime} / \mathrm{H}-4^{\prime} / \mathrm{H}-5^{\prime} / \mathrm{C}-6^{\prime}$, and $\mathrm{H}_{2}-7^{\prime} / \mathrm{H}_{2}-8^{\prime}$, along with $\mathrm{HMBC}$ correlations from $\mathrm{H}-3$ to $\mathrm{C}-4 \mathrm{a}$ and $\mathrm{C}-8^{\prime}$, from $\mathrm{H}-5$ and $\mathrm{H}-7$ to $\mathrm{C}-8 \mathrm{a}$, from $\mathrm{H}-2^{\prime}$ and $\mathrm{H}-6^{\prime}$ to $\mathrm{C}-7^{\prime}$, from $\mathrm{H}_{2}-7^{\prime}$ to $\mathrm{C}-2, \mathrm{C}-2^{\prime}$, and $\mathrm{C}-6^{\prime}$, and from $\mathrm{H}_{2}-8^{\prime}$ to $\mathrm{C}-1^{\prime}$ and $\mathrm{C}-3$, were observed, which implied the presence of a 5,6,7,8-tetrahydroxy-5,6,7,8tetrahydro-2-(2-phenylethyl)chromone moiety in $\mathbf{5}$. In unit $\mathrm{B}$ of 5 (Fig. 2), two ${ }^{1} \mathrm{H}-{ }^{1} \mathrm{H}$ COSY fragments, $\mathrm{H}-2^{\prime}$ ' $\mathrm{H}-3^{\prime} / \mathrm{H}-4^{\prime} / \mathrm{H}-5^{\prime} / \mathrm{C}-6^{\prime}$ and $\mathrm{H}_{2}-7^{\prime} / \mathrm{H}_{2}-8^{\prime}$, along with $\mathrm{HMBC}$ correlations from $\mathrm{H}-3$ to $\mathrm{C}-4 \mathrm{a}$ and $\mathrm{C}-8^{\prime}$, from $\mathrm{H}-5$ to $\mathrm{C}-4$ and $\mathrm{C}-8 \mathrm{a}$, from 7-OMe to $\mathrm{C}-7$, from $\mathrm{H}-8$ to $\mathrm{C}-4 \mathrm{a}$ and $\mathrm{C}-6$, from $\mathrm{H}-2^{\prime}$ and $\mathrm{H}-6^{\prime}$ to $\mathrm{C}-7^{\prime}$, from $\mathrm{H}_{2}-7^{\prime}$ to $\mathrm{C}-2$, $\mathrm{C}-2^{\prime}$, and $\mathrm{C}-6^{\prime}$, and from $\mathrm{H}_{2}-8^{\prime}$ to $\mathrm{C}-1^{\prime}$ and $\mathrm{C}-3$, were observed, which implied the presence of a 6-hydroxy-7-methoxy2-(2-phenylethyl)chromone moiety in 5. Units A and B were connected through an ether bond by the HMBC correlation from $\mathrm{H}-8$ of unit A to $\mathrm{C}-6$ of unit B (Fig. 2). The relative configuration of unit $\mathrm{A}$ was deduced to be

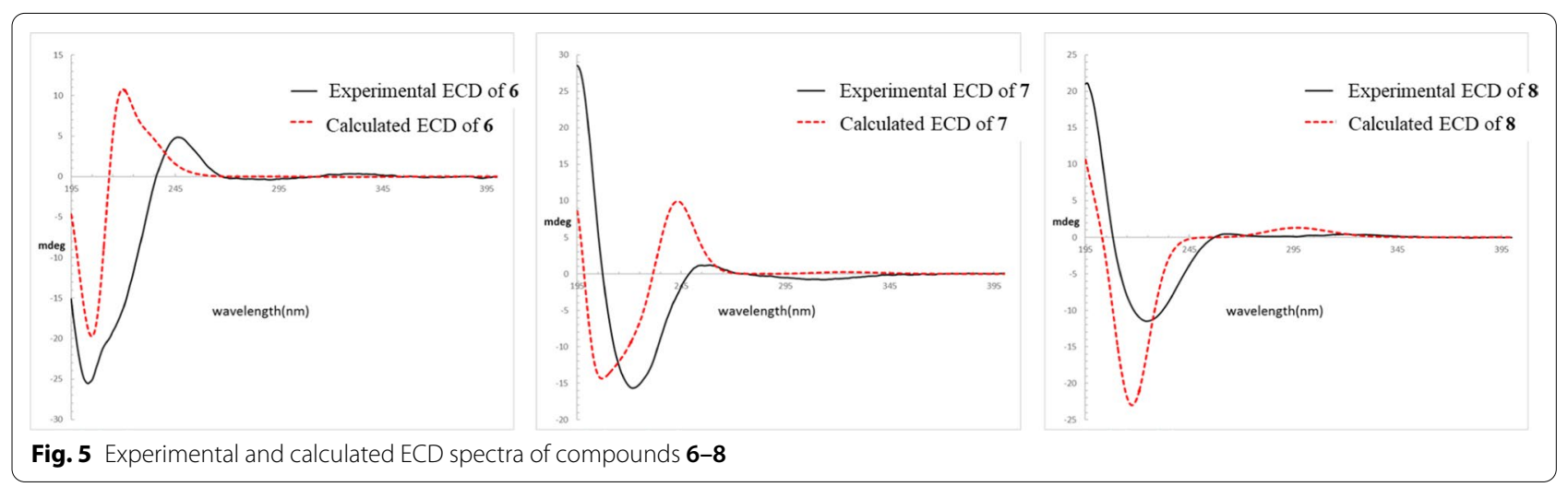


the same as that of a structural analog $(5 S, 6 R, 7 S, 8 R)-2$ (2-phenylethyl)-5,6,7-trihydroxy-5,6,7,8-tetrahydro8-[2-(2-phenylethyl)chromonyl-6-oxy]chromone [11] by comparing the coupling constants of H-5 to H-8 $\left(J_{5,6}=6.9 \mathrm{~Hz}, J_{6.7}=9.6 \mathrm{~Hz}\right.$, and $\left.J_{7.8}=7.3 \mathrm{~Hz}\right)$ in 5 with those $\left(J_{5,6}=7.0 \mathrm{~Hz}, J_{6.7}=9.8 \mathrm{~Hz}\right.$, and $\left.J_{7.8}=7.5 \mathrm{~Hz}\right)$ of $\mathrm{H}-5$ to $\mathrm{H}-8$ in the known analog [11]. The absolute configuration of 5 was suggested to be $(5 S, 6 R, 7 S, 8 R)-2$ (2-phenylethyl)-5,6,7-trihydroxy-5,6,7,8-tetrahydro-8-[2(2-phenylethyl)-7-methoxychromonyl-6-oxy]chromone because the ECD spectrum of $\mathbf{5}$ was similar to that of (5S,6R,7S,8R)-2-(2-phenylethyl)-5,6,7-trihydroxy-5,6,7,8tetrahydro-8-[2-(2-phenylethyl)chromonyl-6-oxy]chromone (20) (Fig. 4).

Compound 6 was assigned the molecular formula $\mathrm{C}_{15} \mathrm{H}_{20} \mathrm{O}_{4}$, as determined by ${ }^{13} \mathrm{C}$ NMR data (Table 4) and the positive ion at $\mathrm{m} / z 287.1255[\mathrm{M}+\mathrm{Na}]^{+}$(calcd for $\mathrm{C}_{15} \mathrm{H}_{20} \mathrm{NaO}_{4}, 287.1259$ ) in the HRESIMS. The ${ }^{1} \mathrm{H}$ and ${ }^{13} \mathrm{C}$ NMR data (Table 4) indicated the presence of one $\alpha, \beta$-unsaturated ketone $\left[\delta_{\mathrm{H}} 5.91\right.$ (br s); $\delta_{\mathrm{C}} 214.1$, 188.3 , and 130.4], one exocyclic double bond [ $\delta_{\mathrm{H}} 5.55$ (br s) and 5.36 (br s); $\delta_{\mathrm{C}} 156.3$ and 112.3], two methyl groups $\left[\delta_{\mathrm{H}} 1.29(\mathrm{~s})\right.$ and $1.14(\mathrm{~d}, J=7.4 \mathrm{~Hz}) ; \delta_{\mathrm{C}} 25.2$ and 15.4], one methylene, four methines including two oxygenated groups $\left[\delta_{\mathrm{H}} 4.12(\mathrm{t}, J=2.2 \mathrm{~Hz})\right.$ and 3.88 (dd, $J=10.7,5.3 \mathrm{~Hz}$ ); $\delta_{\mathrm{C}} 75.4$ and 71.8 ], and two quaternary carbon atoms $\left(\delta_{\mathrm{C}} 77.3\right.$ and 42.8$)$. Its NMR data were similar to those of $(4 R, 5 S, 7 R, 8 S, 10 S, 13 R)-8,13-\mathrm{di}$ - hydroxyrotunda-1,11-dien-3-one with a rare tricyclic rotundane skeleton [5]. According to the ${ }^{1} \mathrm{H}-{ }^{1} \mathrm{H}$ COSY correlations (Fig. 2), two fragments, C-15-C-4-C-5-C-6 and $\mathrm{C}-8-\mathrm{C}-9$, were deduced. According to $\mathrm{HMBC}$ correlations (Fig. 2) from $\mathrm{H}-2$ to $\mathrm{C}-4$ and $\mathrm{C}-5$, from $\mathrm{H}_{3}-15$ to $\mathrm{C}-3, \mathrm{C}-4$, and $\mathrm{C}-5$, from $\mathrm{H}_{2}-6$ to $\mathrm{C}-1, \mathrm{C}-8$, and $\mathrm{C}-11$, from $\mathrm{H}_{2}-12$ to $\mathrm{C}-7$ and $\mathrm{C}-13$, and from $\mathrm{H}_{3}-14$ to $\mathrm{C}-1$, $\mathrm{C}-9, \mathrm{C}-10$, and $\mathrm{C}-13$, the planar structure of $\mathbf{6}$ was elucidated to be 7,8,13-trihydroxyrotunda-1,11-dien3-one. The ROESY correlations (Fig. 2) of $\mathrm{H}_{3}-15 / \mathrm{H}-5$ and $\mathrm{H}-5 / \mathrm{H}-9 \alpha$ indicated that these protons should be cofacial; the ROESY correlations of $\mathrm{H}-9 \beta / \mathrm{H}-13$ and $\mathrm{H}-8 / \mathrm{H}-13$ indicated that these protons should also be cofacial. Thus, the relative configuration of $\mathbf{6}$ was determined, as shown in Fig. 2. By comparing its experimental and calculated ECD spectra (Fig. 5), the structure of compound 6 was finally elucidated to be $(4 S, 5 S, 7 S, 8 S, 1$ $0 S, 13 R)$-7,8,13-trihydroxyrotunda-1,11-dien-3-one.

Compound 7 has the molecular formula $\mathrm{C}_{15} \mathrm{H}_{20} \mathrm{O}_{4}$ according to its ${ }^{13} \mathrm{C}$ NMR data (Table 4) and HRESIMS at $287.1253[\mathrm{M}+\mathrm{Na}]^{+}$(calcd for $\mathrm{C}_{15} \mathrm{H}_{20} \mathrm{NaO}_{4}$, 287.1259). Its ${ }^{13} \mathrm{C}$ NMR data exhibited 15 signals for one $\alpha, \beta$-unsaturated ketone functionality $\left(\delta_{\mathrm{C}} 214.1\right.$, 191.5 , and 128.5$)$, one exocyclic double bond $\left(\delta_{\mathrm{C}} 156.3\right.$ and 116.5), two quaternary carbon atoms $\left(\delta_{\mathrm{C}} 77.1\right.$ and 43.7), one methine, four methylenes including two oxygenated groups $\left(\delta_{\mathrm{C}} 78.5\right.$ and 71.7), and two methyl groups $\left(\delta_{\mathrm{C}} 24.5\right.$ and 15.9). The NMR data of compounds

Table $4{ }^{1} \mathrm{H}$ and ${ }^{13} \mathrm{C}$ NMR data of $\mathbf{6 - 8}$ in methanol- $d_{4}(\delta$ in ppm, $J$ in $\mathrm{Hz})$

\begin{tabular}{|c|c|c|c|c|c|c|}
\hline \multirow[t]{2}{*}{ No } & \multicolumn{2}{|l|}{6} & \multicolumn{2}{|l|}{7} & \multicolumn{2}{|l|}{8} \\
\hline & $\overline{\delta_{\mathrm{H}}{ }^{a}}$ & $\delta_{C}^{b}$ & $\overline{\delta_{H}{ }^{c}}$ & $\delta_{C}^{d}$ & $\overline{\delta_{H}{ }^{c}}$ & $\delta_{C}{ }^{d}$ \\
\hline 1 & & 188.3 & & 191.5 & & 191.7 \\
\hline 2 & $5.91(\mathrm{br} \mathrm{s})$ & 130.4 & $5.95(d, 1.6)$ & 128.5 & $5.88(d, 1.4)$ & 128.5 \\
\hline 3 & & 214.1 & & 214.1 & & 214.5 \\
\hline 4 & $1.87(\mathrm{~m})$ & 51.1 & $1.89(\mathrm{qd}, 7.5,2.1)$ & 51.5 & $2.60(\mathrm{~m})$ & 45.5 \\
\hline 5 & $2.98(\mathrm{~m})$ & 47.0 & $3.02(\mathrm{~m})$ & 47.3 & $3.62(\mathrm{~m})$ & 41.6 \\
\hline $\begin{array}{l}6 a \\
6 \beta\end{array}$ & $\begin{array}{l}2.75(\mathrm{dd}, 12.5,8.9) \\
1.35(\mathrm{t}, 12.5)\end{array}$ & 45.9 & $\begin{array}{l}2.83(\mathrm{dd}, 12.3,9.3) \\
1.26(\mathrm{ddd}, 12.3,10.2,1.2)\end{array}$ & 46.8 & $\begin{array}{l}2.46(\mathrm{dd}, 12.1,8.8) \\
1.22(\mathrm{ddd}, 12.1,11.1,1.1)\end{array}$ & 43.2 \\
\hline 7 & & 77.3 & & 77.1 & & 77.4 \\
\hline 8 & $3.88(\mathrm{dd}, 10.7,5.3)$ & 71.8 & 4.11 (ddd, 10.5, 6.0, 1.2) & 71.7 & 4.09 (ddd, 10.6, 5.6, 0.9) & 71.8 \\
\hline $\begin{array}{l}9 a \\
9 \beta\end{array}$ & $\begin{array}{l}1.88(\mathrm{~m}) \\
2.05(\mathrm{dd}, 15.0,10.7)\end{array}$ & 41.5 & $\begin{array}{l}1.73(\mathrm{ddd}, 14.5,6.0,1.0) \\
2.31(\mathrm{dd}, 14.5,10.5)\end{array}$ & 38.6 & $\begin{array}{l}1.81(\mathrm{ddd}, 14.5,5.6,0.9) \\
2.33(\mathrm{dd}, 14.5,10.7)\end{array}$ & 38.4 \\
\hline 10 & & 44.8 & & 43.7 & & 43.6 \\
\hline 11 & & 156.3 & & 156.3 & & 156.3 \\
\hline 12 & $\begin{array}{l}5.55 \text { (br s) } \\
5.36 \text { (br s) }\end{array}$ & 112.3 & $\begin{array}{l}5.54(\mathrm{~d}, 0.8) \\
5.19(\mathrm{br} \mathrm{s})\end{array}$ & 116.5 & $\begin{array}{l}5.53(\mathrm{~s}) \\
5.17(\mathrm{~s})\end{array}$ & 116.5 \\
\hline 13 & $4.12(t, 2.2)$ & 75.4 & $3.88(s)$ & 78.5 & 3.89 (br s) & 78.6 \\
\hline 14 & $1.29(\mathrm{~s})$ & 25.2 & $1.30(\mathrm{~s})$ & 24.5 & $1.29(\mathrm{~s})$ & 24.5 \\
\hline 15 & $1.14(d, 7.4)$ & 15.4 & $1.15(d, 7.5)$ & 15.9 & $1.02(d, 7.6)$ & 10.5 \\
\hline
\end{tabular}

${ }^{\text {a }}$ Measured at $500 \mathrm{MHz} ;{ }^{\mathrm{b}}$ measured at $126 \mathrm{MHz} ;{ }^{\mathrm{c}}$ measured at $800 \mathrm{MHz} ;{ }^{\mathrm{d}}$ measured at $201 \mathrm{MHz}$ 
6 and 7 were very close to each other, and both of these compounds have the same molecular formula, which implied that compound 7 might also be a rotundanetype sesquiterpenoid.

The ${ }^{1} \mathrm{H}-{ }^{1} \mathrm{H}$ COSY fragments $\mathrm{H}_{3}-15 / \mathrm{H}-4 / \mathrm{H}-5 / \mathrm{H}_{2}-6$ and $\mathrm{H}-8 / \mathrm{H}_{2}-9$ were determined from the ${ }^{1} \mathrm{H}-{ }^{1} \mathrm{H}$ COSY correlations of 7 (Fig. 2). Based on the HMBC correlations (Fig. 2) from $\mathrm{H}-2$ to $\mathrm{C}-4$ and $\mathrm{C}-5$, from $\mathrm{H}_{3}-15$ to $\mathrm{C}-3$, C-4, and $\mathrm{C}-5$, from $\mathrm{H}_{2}-6$ to $\mathrm{C}-1, \mathrm{C}-8$, and $\mathrm{C}-11$, from $\mathrm{H}_{2}-12$ to $\mathrm{C}-7$ and $\mathrm{C}-13$, and from $\mathrm{H}_{3}-14$ to $\mathrm{C}-1, \mathrm{C}-9, \mathrm{C}-10$, and $\mathrm{C}-13$, the planar structure of 7 was elucidated to be the same as that of compound $\mathbf{6}$, namely, 7,8,13-trihydroxyrotunda-1,11-dien-3-one. Because $J_{8,9 \alpha}(6.0 \mathrm{~Hz})$ and $J_{8,9 \beta}$ $(10.5 \mathrm{~Hz})$ values in the ${ }^{1} \mathrm{H}$ NMR data of compound 7 were similar to those $J_{8,9 \alpha}=5.3 \mathrm{~Hz}$ and $\left.J_{8,9 \beta}=10.8 \mathrm{~Hz}\right)$ of compound $6, \mathrm{H}-8$ in compound 7 was elucidated to be $\beta$-oriented. Correlations of $\mathrm{H}_{3}-15 / \mathrm{H}-5, \mathrm{H}-5 / \mathrm{H}-9 \alpha$, and $\mathrm{H}-2 / \mathrm{H}-13$ were observed in the ROESY spectrum (Fig. 2), indicating that compound 7 is a $\mathrm{C}-13$ epimer of compound 6. Finally, the absolute configuration of 7 was elucidated to be $(4 S, 5 S, 7 S, 8 S, 10 S, 13 S)-7,8,13$-trihydroxyrotunda-1,11-dien-3-one based on the ECD calculations (Fig. 5).

Compound 8 was assigned the molecular formula $\mathrm{C}_{15} \mathrm{H}_{20} \mathrm{O}_{4}$, the same as that of 6 and 7 , by ${ }^{13} \mathrm{C}$ NMR data (Table 4) and the ion peak at $m / z 264.1359$ [M] $^{+}$(calcd for $\mathrm{C}_{15} \mathrm{H}_{20} \mathrm{O}_{4}, 264.1362$ ) in the HREIMS. The ${ }^{1} \mathrm{H}$ and ${ }^{13} \mathrm{C}$ NMR data (Table 4) indicated that this compound might also be a rotundane-type sesquiterpenoid with one $\alpha, \beta$ unsaturated ketone functionality $\left(\delta_{\mathrm{C}} 214.5,191.7\right.$, and $128.5)$, one exocyclic double bond $\left(\delta_{\mathrm{C}} 156.3\right.$ and 116.5), two quaternary carbon atoms $\left(\delta_{\mathrm{C}} 77.4\right.$ and 43.6$)$, one methine, four methylenes including two oxygenated groups $\left(\delta_{\mathrm{C}} 78.6\right.$ and 71.8$)$, and two methyl groups $\left(\delta_{\mathrm{C}} 24.5\right.$ and 10.5). Based on its ${ }^{1} \mathrm{H}-{ }^{1} \mathrm{H}$ COSY and HMBC correlations (Fig. 2), the planar structure of $\mathbf{8}$, namely, 7,8,13-trihydroxyrotunda-1,11-dien-3-one, was deduced to be the same as that of compounds 6 and 7. The H- $4 \alpha, \mathrm{H}-5 \alpha$, $\mathrm{H}-8 \beta$, and $\mathrm{H}-13 \beta$ configurations were determined by the key ROESY correlations of $\mathrm{H}_{3}-15 / \mathrm{H}-6 \alpha, \mathrm{H}_{3}-15 / \mathrm{H}-6 \beta$, $\mathrm{H}-5 / \mathrm{H}-9 \alpha$, and $\mathrm{H}-2 / \mathrm{H}-13$ (Fig. 2 ) and by comparing $J$ values in its ${ }^{1} \mathrm{H}$ NMR spectrum with those of compounds $\mathbf{6}$ and 7. Finally, the absolute configuration of 8 was elucidated to be $(4 R, 5 S, 7 S, 8 S, 10 S, 13 S)-7,8,13$-trihydroxyrotunda-1,11-dien-3-one, a C-4 epimer of 7, based on the ECD calculations (Fig. 5).

NMR data of C-5 to C-8 in agarotetrol (9) were not correctly assigned before [7, 8], which were revised by 2D NMR correlations (Additional file 1: Fig. S2). NMR data of 4'-methoxyagarotetrol (11) in DMSO- $d_{6}$ [12], 2 '-hydroxyagarotetrol (13) in DMSO- $d_{6}[13],(5 S, 6 R, 7 R, 8 S)$ 2-(2-phenylethyl)-5,6,7-trihydroxy-5,6,7,8-tetrahydro-8[2-(2-phenylethyl)chromonyl-6-oxy]chromone

(19) in
Table 5 The effects of compounds at a single concentration on PC12 cell injury induced by corticosterone ${ }^{a}$

\begin{tabular}{|c|c|c|}
\hline Compound & $\begin{array}{l}\text { Concentration } \\
(\mu \mathrm{M})\end{array}$ & Survival rate \pm SD $(\%)^{b}$ \\
\hline Blank & - & $100.00 \pm 0.22^{* * *}$ \\
\hline Negative control & - & $59.92 \pm 0.33$ \\
\hline $\begin{array}{l}\text { Desipramine (positive } \\
\text { control) }\end{array}$ & 10 & $89.66 \pm 0.78^{* * *}$ \\
\hline 1 & 20 & $60.24 \pm 0.51$ \\
\hline 2 & 20 & $59.27 \pm 1.01$ \\
\hline 4 & 20 & $72.14 \pm 1.35^{* * *}$ \\
\hline 6 & 20 & $74.79 \pm 0.73^{* * *}$ \\
\hline 7 & 20 & $63.10 \pm 0.82^{* *}$ \\
\hline 9 & 20 & $79.50 \pm 1.79^{* * *}$ \\
\hline 10 & 20 & $68.50 \pm 1.43^{* * *}$ \\
\hline 11 & 20 & $65.28 \pm 1.54^{* *}$ \\
\hline 12 & 20 & $71.64 \pm 1.08^{* * *}$ \\
\hline 17 & 20 & $76.24 \pm 1.10^{* * *}$ \\
\hline Blank & - & $100.00 \pm 0.73^{* * *}$ \\
\hline Negative control & - & $60.83 \pm 0.93$ \\
\hline $\begin{array}{l}\text { Desipramine (positive } \\
\text { control) }\end{array}$ & 10 & $90.07 \pm 0.45^{* * *}$ \\
\hline 5 & 20 & $60.26 \pm 1.14$ \\
\hline 8 & 20 & $60.18 \pm 1.84$ \\
\hline 13 & 20 & $54.29 \pm 1.04$ \\
\hline 14 & 20 & $60.16 \pm 1.20$ \\
\hline 15 & 20 & $67.07 \pm 1.27^{* *}$ \\
\hline 16 & 20 & $59.47 \pm 0.81$ \\
\hline 18 & 20 & $60.27 \pm 1.24$ \\
\hline 19 & 20 & $60.27 \pm 1.55$ \\
\hline 20 & 20 & $65.69 \pm 0.57^{* *}$ \\
\hline 21 & 20 & $71.34 \pm 1.01^{* * *}$ \\
\hline 22 & 20 & $60.55 \pm 1.21$ \\
\hline
\end{tabular}

${ }^{a}$ The concentration of corticosterone was $150 \mu \mathrm{M}$

${ }^{\mathrm{b}}$ Compared with the negative control, ${ }^{* *} P<0.01,{ }^{* * *} P<0.001$

DMSO- $d_{6}$ [14], and (-)-aquisinenone G (21) in $\mathrm{CDCl}_{3}$ [15] have been reported in the literature. Their NMR data in methanol $-d_{4}$ are presented in this paper. Other known compounds, isoagarotetrol (10) [8], 4'-methoxyisoagarotetrol (12) $\quad[16], \quad\left(5 S, 6 R, 7 S, 8 R, 7^{\prime} R\right)-7^{\prime}$-hydroxyisoagarotetrol (15) $\quad[10], \quad\left(5 S, 6 R, 7 S, 8 R, 7^{\prime} S\right)-7^{\prime}$-hydroxyisoagarotetrol (16) $\quad[10], \quad(5 S, 6 S, 7 S, 8 R)-8$-chloro-2-(2-phenylethyl)-5,6 ,7-trihydroxy-5,6,7,8-tetrahydrochromone (14) [5, 17], 6-hydroxy-2-(2-phenylethyl)chromone (17) [18], 2,2'-di(2-phenylethyl)-8,6'-dihydroxy-5,5'-bichromone (18) [19], (5R,6R,7R,8S)-2-(2-phenylethyl)-5,6,7-trihydroxy-5,6,7,8tetrahydro-8-[2-(2-phenylethyl)chromonyl-6-oxy]chromone (20) [11], and syringin (22) [20], were identified by comparing their spectroscopic data with those in literature. 
Rat adrenal pheochromocytoma (PC12) cell injury induced by corticosterone is an in vitro model for screening neuroprotective and antidepressant compounds [6]. All isolates except for compound $\mathbf{3}$ were evaluated for their protective activities against corticosterone-induced damage in PC12 cells. After testing these compounds at a single concentration of $20 \mu \mathrm{M}$ (Table 5), several compounds were selected for testing at gradient concentrations of $2.5,5,10,20$, and $40 \mu \mathrm{M}$. Among them, $(6 S, 7 S, 8 R)$-2-(2-phenylethyl)-6,7,8-trihydroxy-5,6,7,8-tetrahydrochromone (4), (4S,5S,7S,8S,10S,13R)-7,8,13-trihydroxyrotunda-1,11-dien-3-one (6), agarotetrol (9), and 6-hydroxy-2-(2-phenylethyl)chromone (17) showed the most protective activities against corticosterone-induced PC12 cell injury at concentrations from 5 to $40 \mu \mathrm{M}$ $(P<0.001)$ (Table 6). Among the chromone derivatives (1-5 and 9-21), the types and positions of substituent groups seem to have effects on the activity, although no obvious patterns of structure-activity relationships (SAR) were observed. Nevertheless, a hydroxy substituent at $\mathrm{C}-2^{\prime}$ or $\mathrm{C}-7^{\prime}$ would reduce the activity by comparing the bioassay data of agarotetrol (9) and their derivatives (1, 2, 11, and 13) (Tables 5 and 6).

\section{Experimental section}

\subsection{General experimental procedures}

The material and instruments used for isolating compounds and measuring spectroscopic data are provided in the Additional file 1.

\subsection{Plant material}

The plant material was purchased from the Flagship Store of Jiabaohua Pharmacy, Zhuhai, Guangdong, China (order number: 172979790097330735) in June 2018, produced by Guangdong Huiqun Chinese Traditional Medicine Co., Ltd., Shantou, Guangdong, China (lot number: 20171101), and identified as the resinous heartwood of Aquilaria sinensis (Lour.) Spreng. by Professor Shu-De Yang at Yunnan University of Traditional Chinese Medicine, China. The voucher specimen (No. GD171101) was kept in the Key Laboratory of Economic Plants and Biotechnology, Kunming Institute of Botany, Chinese Academy of Sciences.

\subsection{Extraction and isolation}

The dried resinous heartwood of $A$. sinensis $(2.9 \mathrm{~kg})$ was ultrasonically extracted with $90 \% \mathrm{EtOH}(10 \mathrm{~L} \times 5)$ at $60{ }^{\circ} \mathrm{C}$ for half an hour each time. The crude extract $(459.3 \mathrm{~g})$ was suspended in $1 \mathrm{~L}$ of water, followed by
Table 6 The effects of compounds at gradient concentrations on PC12 cell injury induced by corticosterone ${ }^{a}$

\begin{tabular}{|c|c|c|}
\hline Compound & Concentration $(\mu \mathrm{M})$ & Survival rate \pm SD $(\%)^{b}$ \\
\hline Blank & - & $100.01 \pm 0.77^{* * *}$ \\
\hline Negative control & - & $60.29 \pm 0.44$ \\
\hline $\begin{array}{l}\text { Desipramine (positive } \\
\text { control) }\end{array}$ & 10 & $89.74 \pm 0.58^{* * *}$ \\
\hline \multirow[t]{5}{*}{4} & 40 & $70.30 \pm 0.12^{* * *}$ \\
\hline & 20 & $72.18 \pm 0.33^{* * *}$ \\
\hline & 10 & $67.46 \pm 0.61^{* * *}$ \\
\hline & 5 & $64.05 \pm 0.50^{* * *}$ \\
\hline & 2.5 & $60.39 \pm 0.50$ \\
\hline \multirow[t]{5}{*}{6} & 40 & $71.77 \pm 0.39^{* * *}$ \\
\hline & 20 & $74.22 \pm 0.54^{* * *}$ \\
\hline & 10 & $69.90 \pm 0.26^{* * *}$ \\
\hline & 5 & $66.76 \pm 0.79^{* * *}$ \\
\hline & 2.5 & $60.18 \pm 0.53$ \\
\hline \multirow[t]{5}{*}{7} & 40 & $68.02 \pm 0.44^{* * *}$ \\
\hline & 20 & $63.67 \pm 0.27^{* * *}$ \\
\hline & 10 & $60.79 \pm 0.42$ \\
\hline & 5 & $60.16 \pm 0.25$ \\
\hline & 2.5 & $59.97 \pm 0.39$ \\
\hline \multirow[t]{5}{*}{9} & 40 & $72.00 \pm 0.98^{* * *}$ \\
\hline & 20 & $79.11 \pm 0.80^{* * *}$ \\
\hline & 10 & $73.53 \pm 0.39^{* * *}$ \\
\hline & 5 & $64.87 \pm 0.49^{* * *}$ \\
\hline & 2.5 & $60.17 \pm 0.41$ \\
\hline \multirow[t]{5}{*}{10} & 40 & $66.05 \pm 0.21^{* * *}$ \\
\hline & 20 & $68.63 \pm 1.05^{* * *}$ \\
\hline & 10 & $64.60 \pm 0.27^{* * *}$ \\
\hline & 5 & $60.06 \pm 0.34$ \\
\hline & 2.5 & $60.21 \pm 0.30$ \\
\hline \multirow[t]{5}{*}{11} & 40 & $70.06 \pm 0.15^{* * *}$ \\
\hline & 20 & $65.87 \pm 0.37^{* * *}$ \\
\hline & 10 & $63.91 \pm 0.19^{* * *}$ \\
\hline & 5 & $59.97 \pm 0.36$ \\
\hline & 2.5 & $60.13 \pm 0.38$ \\
\hline \multirow[t]{5}{*}{12} & 40 & $71.66 \pm 0.22^{* * *}$ \\
\hline & 20 & $70.86 \pm 0.54^{* * *}$ \\
\hline & 10 & $63.50 \pm 0.85^{* *}$ \\
\hline & 5 & $62.01 \pm 0.54^{*}$ \\
\hline & 2.5 & $59.98 \pm 0.39$ \\
\hline \multirow[t]{5}{*}{17} & 40 & $77.87 \pm 0.70^{* * *}$ \\
\hline & 20 & $76.06 \pm 0.40^{* * *}$ \\
\hline & 10 & $71.62 \pm 0.40^{* * *}$ \\
\hline & 5 & $66.26 \pm 1.07^{* * *}$ \\
\hline & 2.5 & $60.39 \pm 0.50$ \\
\hline
\end{tabular}

${ }^{a}$ The concentration of corticosterone was $150 \mu \mathrm{M}$

${ }^{\mathrm{b}}$ Compared with the negative control, ${ }^{*} P<0.05,{ }^{* *} P<0.01,{ }^{* * *} P<0.001$ 
extraction with petroleum ether $(1 \mathrm{~L} \times 5)$, EtOAc $(1$ $\mathrm{L} \times 5)$, and $n-\mathrm{BuOH}(1 \mathrm{~L} \times 5)$. After removing the solvent, the petroleum ether-soluble fraction $(0.7 \mathrm{~g})$, EtOAcsoluble fraction $(374.8 \mathrm{~g})$, and $n-\mathrm{BuOH}$-soluble fraction $(55.9 \mathrm{~g})$ were obtained.

The $n-\mathrm{BuOH}$-soluble fraction (55.9 g) was separated by a silica gel column with EtOAc/MeOH $(100: 0 \rightarrow 0: 1$, $\mathrm{v} / \mathrm{v}$ ) as the eluent to yield five further fractions (Fr. 1 to Fr. 5). Fr. 1 (786.8 mg) was subjected to a reversed-phase $(\mathrm{RP}) \mathrm{C}_{18}$ silica gel column $\left(\mathrm{MeOH} / \mathrm{H}_{2} \mathrm{O}, 5 \% \rightarrow 100 \%\right)$ to yield 10 further fractions (Fr. 1-1 to Fr. 1-10). Compound $17(2.1 \mathrm{mg})$ is obtained from Fr. 1-6 by recrystallization $(\mathrm{MeOH})$.

Fr. $2(16.7 \mathrm{~g})$ was purified by an $\mathrm{RP} \mathrm{C}_{18}$ column $\left(\mathrm{MeOH} / \mathrm{H}_{2} \mathrm{O}, 5 \% \rightarrow 100 \%\right)$ to yield 13 further fractions (Fr. 2-1 to Fr. 2-13). Fr. 2-6 was recrystallized from $\mathrm{MeOH}$ to yield $9(1.1 \mathrm{~g})$. Fr. 2-3 $(456.6 \mathrm{mg})$ was applied to a silica gel column via elution by $\mathrm{CH}_{2} \mathrm{Cl}_{2} / \mathrm{MeOH}$ $(50: 1 \rightarrow 1: 1)$ to yield five further fractions (Fr. 2-3-1 to Fr. 2-3-5). Fr. 2-3-2 (114.7 mg) was purified by semipreparative HPLC (Welch Ultimate AQ-C $18, \phi 7.8 \times 250 \mathrm{~mm}$; $\left.\mathrm{MeOH} / \mathrm{H}_{2} \mathrm{O}, 20: 80, v=2 \mathrm{~mL} / \mathrm{min}\right)$ to yield $6(10.6 \mathrm{mg}$, $\left.t_{\mathrm{R}}=15.072 \mathrm{~min}\right)$ and $7\left(11.9 \mathrm{mg}, t_{\mathrm{R}}=22.831 \mathrm{~min}\right)$. Fr. 2-3-5 (58.3 $\mathrm{mg}$ ) was further purified by semipreparative HPLC (Welch Ultimate AQ- $\mathrm{C}_{18}, \phi 7.8 \times 250 \mathrm{~mm}$; $\left.\mathrm{MeOH} / \mathrm{H}_{2} \mathrm{O}, 40: 60, v=2 \mathrm{~mL} / \mathrm{min}\right)$ to yield $1(14.1 \mathrm{mg}$, $\left.t_{\mathrm{R}}=9.282 \mathrm{~min}\right)$ and $2\left(7.1 \mathrm{mg}, t_{\mathrm{R}}=10.161 \mathrm{~min}\right)$. Fr. $2-3-4$ (41.3 mg) was separated by a silica gel column $\left(\mathrm{CH}_{2} \mathrm{Cl}_{2} /\right.$ $\mathrm{MeOH}, 30: 1 \rightarrow 1: 1)$ and was then purified by semipreparative HPLC (Welch Ultimate AQ- $\mathrm{C}_{18}, \phi 7.8 \times 250 \mathrm{~mm}$; $\left.\mathrm{MeCN} / \mathrm{H}_{2} \mathrm{O}, 10: 90, v=2 \mathrm{~mL} / \mathrm{min}\right)$ to yield $15(1.5 \mathrm{mg}$, $\left.t_{\mathrm{R}}=22.158 \mathrm{~min}\right)$. Fr. 2-8 (524.3 mg) was separated by a silica gel column $\left(\mathrm{CH}_{2} \mathrm{Cl}_{2} / \mathrm{MeOH}, 50: 1\right)$ to yield 11 further fractions (Fr. 2-8-1 to Fr. 2-8-11). Fr. 2-8-6 was recrystallized from $\mathrm{MeOH}$ to yield 12 (204.0 mg). Fr. 2-8-9 (51.3 $\mathrm{mg}$ ) was purified by semipreparative HPLC (Welch Ultimate AQ- $\mathrm{C}_{18}, \phi 7.8 \times 250 \mathrm{~mm} ; \mathrm{MeOH} / \mathrm{H}_{2} \mathrm{O}$, $30: 70, v=2 \mathrm{~mL} / \mathrm{min})$ to yield $4\left(4.2 \mathrm{mg}, t_{\mathrm{R}}=37.011 \mathrm{~min}\right)$ and $3\left(2.0 \mathrm{mg}, t_{\mathrm{R}}=41.898 \mathrm{~min}\right)$. Fr. $2-8-10$ (49.3 mg) was applied to a silica gel column via elution by $\mathrm{CH}_{2} \mathrm{Cl}_{2} / \mathrm{MeOH}$ (30:1 $\left.\rightarrow 1: 1\right)$ and was further purified by semipreparative HPLC (Welch Ultimate AQ- $\mathrm{C}_{18}$, $\left.\phi 7.8 \times 250 \mathrm{~mm} ; \mathrm{MeOH} / \mathrm{H}_{2} \mathrm{O}, 33: 67, v=2 \mathrm{~mL} / \mathrm{min}\right)$ to yield $11\left(1.4 \mathrm{mg}, t_{\mathrm{R}}=21.190 \mathrm{~min}\right)$. Fr. $2-9(489.4 \mathrm{mg})$ was applied to a silica gel column and eluted with $\mathrm{CH}_{2} \mathrm{Cl}_{2} /$ $\mathrm{MeOH}(100: 1 \rightarrow 1: 1)$ to yield five further fractions (Fr. 2-9-1 to Fr. 2-9-5). Fr. 2-9-2 (118.8 mg) was separated by Sephadex LH-20 (MeOH) and was further purified by semipreparative HPLC (YMC-Pack ODS-A, $\phi$ $10 \times 250 \mathrm{~mm} ; \mathrm{MeOH} / \mathrm{H}_{2} \mathrm{O}, 40: 60, v=2 \mathrm{~mL} / \mathrm{min}$ ) to yield $14\left(2.9 \mathrm{mg}, t_{\mathrm{R}}=14.865 \mathrm{~min}\right)$. Fr $2-9-4(46.9 \mathrm{mg})$ was purified by Sephadex LH-20 (MeOH) to yield $10(4.0 \mathrm{mg})$. Fr 2-12 (599.0 mg) was subjected to a silica gel column via elution by $\mathrm{CH}_{2} \mathrm{Cl}_{2} / \mathrm{MeOH}(100: 1 \rightarrow 1: 1)$ to yield five further fractions (Fr. 2-12-1 to Fr. 2-12-5). Fr. 2-12-1 was recrystallized from $\mathrm{MeOH}$ to yield 18 (1.2 mg). Fr. 2-12-2 (164.1 mg) was applied to a silica gel column $\left(\mathrm{CH}_{2} \mathrm{Cl}_{2} /\right.$ $\mathrm{MeOH}, 100: 1 \rightarrow 1: 1$ ) to yield three further fractions (Fr. 2-12-2-1 to Fr. 2-12-2-3). Fr. 2-12-2-1 (80.0 mg) was purified by semipreparative HPLC (YMC-Pack ODS-A, $\left.\phi 10 \times 250 \mathrm{~mm} ; \mathrm{MeCN} / \mathrm{H}_{2} \mathrm{O}, 48: 52, v=2 \mathrm{~mL} / \mathrm{min}\right)$ to yield 21 (4.0 mg, $\left.t_{\mathrm{R}}=27.886 \mathrm{~min}\right)$. Fr. 2-12-2-3 (60.9 mg) was purified by semipreparative HPLC (Welch Ultimate AQ- $\mathrm{C}_{18}, \phi 7.8 \times 250 \mathrm{~mm} ; \mathrm{MeOH} / \mathrm{H}_{2} \mathrm{O}, 65: 35, v=2 \mathrm{~mL} /$ $\mathrm{min})$ to yield $5\left(2.3 \mathrm{mg}, t_{\mathrm{R}}=26.957 \mathrm{~min}\right)$. Fr. $2-12-4$ $(29.0 \mathrm{mg}$ ) was separated by Sephadex LH-20 gel column chromatography $(\mathrm{MeOH})$ and then by semipreparative HPLC (Welch Ultimate AQ-C $18, \phi 7.8 \times 250 \mathrm{~mm}$; $\left.\mathrm{MeOH} / \mathrm{H}_{2} \mathrm{O}, 65: 35, v=2 \mathrm{~mL} / \mathrm{min}\right)$ to yield $19(3.7 \mathrm{mg}$, $\left.t_{\mathrm{R}}=25.515 \mathrm{~min}\right)$ and $20\left(3.9 \mathrm{mg}, t_{\mathrm{R}}=30.107 \mathrm{~min}\right)$.

Fr. $3(6.0 \mathrm{~g})$ was separated by an $\mathrm{RP} \mathrm{C}_{18}$ silica gel column $\left(\mathrm{MeOH} / \mathrm{H}_{2} \mathrm{O}, 5 \% \rightarrow 100 \%\right)$ to yield 11 further fractions (Fr. 3-1 to Fr. 3-11). Fr. 3-3 (158.0 mg) was separated by a silica gel column $\left(\mathrm{CH}_{2} \mathrm{Cl}_{2} / \mathrm{MeOH}, 50: 1\right)$ and then purified by semipreparative HPLC (Welch Ultimate $\mathrm{AQ}-\mathrm{C}_{18}, \phi 7.8 \times 250 \mathrm{~mm} ; \mathrm{MeOH} / \mathrm{H}_{2} \mathrm{O}, 30: 70$, $\nu=2 \mathrm{~mL} / \mathrm{min})$ to yield $8\left(0.8 \mathrm{mg}, t_{\mathrm{R}}=10.757 \mathrm{~min}\right)$. Fr. $3-4$ $(195.5 \mathrm{mg})$ was separated by a silica gel column $\left(\mathrm{CH}_{2} \mathrm{Cl}_{2} /\right.$ $\mathrm{MeOH}, 50: 1)$ and was then purified by semipreparative HPLC (YMC-Pack ODS-A, $\phi 10 \times 250 \mathrm{~mm} ; \mathrm{MeOH} / \mathrm{H}_{2} \mathrm{O}$, $35: 65, v=2 \mathrm{~mL} / \mathrm{min})$ to yield $22\left(7.1 \mathrm{mg}, t_{\mathrm{R}}=11.198 \mathrm{~min}\right)$ and $16\left(0.9 \mathrm{mg}, t_{\mathrm{R}}=15.727 \mathrm{~min}\right)$. Fr. $3-5(39.0 \mathrm{mg})$ was purified by semipreparative HPLC (YMC-Pack ODS-A, $\phi$ $10 \times 250 \mathrm{~mm} ; \mathrm{MeCN} / \mathrm{H}_{2} \mathrm{O}, 20: 80, v=2 \mathrm{~mL} / \mathrm{min}$ ) to yield $13\left(7.5 \mathrm{mg}, t_{\mathrm{R}}=31.475 \mathrm{~min}\right)$.

\subsection{Spectroscopic data of compounds $1-9,11,13$, and 19-21}

\subsection{1 (5S,6R, $\left.7 R, 8 S, 7^{\prime} P\right)-7^{\prime}$-hydroxyagarotetrol (1)}

Colorless needle crystal $(\mathrm{MeOH}) ;[\alpha]_{\mathrm{D}}^{21}-29.1(c=0.13$, $\mathrm{MeOH}) ; \mathrm{UV}(\mathrm{MeOH}) \lambda_{\max }(\log \varepsilon) 252$ (4.03), 207 (4.17) $\mathrm{nm}$; ECD $\left(c\right.$ 0.013, MeOH) $\lambda_{\max }(\Delta \varepsilon) 298(+0.68), 261$ $(-0.14), 245(+0.13), 222(-1.02), 212(+1.35), 194$ $(+3.92) \mathrm{nm}$; IR $v_{\max }(\mathrm{KBr}) 3406,1658,1601,1448,1089$, 1057, 1039, 1018, $701 \mathrm{~cm}^{-1}$; ${ }^{1} \mathrm{H}$ NMR and ${ }^{13} \mathrm{C}$ NMR data see Table 1; ESIMS (positive) $m / z 357[\mathrm{M}+\mathrm{Na}]^{+}$, $691[2 \mathrm{M}+\mathrm{Na}]^{+}$; HRESIMS (positive) $\mathrm{m} / z 357.0942$ $[\mathrm{M}+\mathrm{Na}]^{+}$(calcd for $\mathrm{C}_{17} \mathrm{H}_{18} \mathrm{NaO}_{7}, 357.0950$ ).

Crystal data of compound 1: $\mathrm{C}_{17} \mathrm{H}_{18} \mathrm{O}_{7} \cdot 2\left(\mathrm{H}_{2} \mathrm{O}\right)$, $M=370.34, \quad a=5.5739(3) \quad \AA, \quad b=8.0353(5) \AA$, $c=19.5345(12) \quad \AA, \quad \alpha=90^{\circ}, \quad \beta=97.596(2)^{\circ}, \quad \gamma=90^{\circ}$, $V=867.23(9) \AA^{3}, T=100(2) \mathrm{K}$, space group $P 1211, Z=2$, $\mu(\mathrm{Cu} \mathrm{K} \alpha)=0.987 \mathrm{~mm}^{-1}, 7517$ reflections measured, 2687 independent reflections $\left(R_{\text {int }}=0.0345\right)$. The final $R_{1}$ values were $0.0287[I>2 \sigma(I)]$. The final $w R\left(F^{2}\right)$ values were $0.0916[I>2 \sigma(I)]$. The final $R_{1}$ values were 0.0292 (all data). 
The final $w R\left(F^{2}\right)$ values were 0.0929 (all data). The goodness of fit on $F^{2}$ was 0.837 . Flack parameter $=0.11(10)$. The crystallographic data for the structure of $\mathbf{1}$ have been deposited in the Cambridge Crystallographic Data Centre (deposition number CCDC 2,118,605). Copies of the data can be obtained free of charge from the CCDC via www.ccdc.cam.ac.uk.

\subsection{2 $\left(5 S, 6 R, 7 R, 8 S, 7^{\prime} \Sigma\right)-7^{\prime}$-hydroxyagarotetrol (2)}

Light yellow powder; $[\alpha]_{\mathrm{D}}^{21}-28.3(c=0.35, \mathrm{MeOH})$; $\mathrm{UV}(\mathrm{MeOH}) \lambda_{\max }(\log \varepsilon) 252$ (3.85), 207 (4.00) nm; ECD $(c 0.018, \mathrm{MeOH}) \lambda_{\max }(\Delta \varepsilon) 301(+0.14), 254(-0.93)$, $223(+1.69) \mathrm{nm}$; IR $v_{\max }(\mathrm{KBr}) 3423,1658,1601,1447$, 1384, 1044, $703 \mathrm{~cm}^{-1} ;{ }^{1} \mathrm{H}$ NMR and ${ }^{13} \mathrm{C}$ NMR data see Table 1; ESIMS (positive) $m / z 357[\mathrm{M}+\mathrm{Na}]^{+}$; HRESIMS (positive) $\mathrm{m} / z 357.0945[\mathrm{M}+\mathrm{Na}]^{+}$(calcd for $\left.\mathrm{C}_{17} \mathrm{H}_{18} \mathrm{NaO}_{7}, 357.0950\right)$.

\subsection{3 (6S,7S,8R)-2-[2-(4-methoxyphenyl)ethyl]-6,7,8-trihy- droxy-5,6,7,8-tetrahydrochromone (3)}

Colorless plate crystal $(\mathrm{MeOH}) ;[\alpha]_{\mathrm{D}}^{27}+7.4(c=0.23$, $\mathrm{MeOH}) ; \mathrm{UV}(\mathrm{MeOH}) \lambda_{\max }(\log \varepsilon) 435$ (1.81), 365 (2.05), 254 (3.88), 220 (3.99), 201(4.04) nm; ECD (c 0.0099, $\mathrm{MeOH}) \lambda_{\max }(\Delta \varepsilon) 221(-1.43) \mathrm{nm} ;{ }^{1} \mathrm{H}$ NMR and ${ }^{13} \mathrm{C}$ NMR data see Table 2; ESIMS (positive) $m / z 302$ $[\mathrm{M}+\mathrm{Na}]^{+}, 627[2 \mathrm{M}+\mathrm{Na}]^{+}$; HRESIMS (positive) $\mathrm{m} / z$ $355.1150[\mathrm{M}+\mathrm{Na}]^{+}$(calcd for $\mathrm{C}_{18} \mathrm{H}_{20} \mathrm{NaO}_{6}, 355.1158$ ).

Crystal data of compound 3: $\mathrm{C}_{18} \mathrm{H}_{20} \mathrm{O}_{6}, M=332.34$, $a=4.9601(2) \quad \AA, \quad b=7.0550(2) \quad \AA, \quad c=23.2769(7)$ $\AA, \quad \alpha=90^{\circ}, \quad \beta=93.5950(10)^{\circ}, \quad \gamma=90^{\circ}, \quad V=812.94(5)$ $\AA^{3}, T=100$.(2) $\mathrm{K}$, space group P1211, $Z=2, \mu(\mathrm{Cu}$ $\mathrm{K} \alpha)=0.850 \mathrm{~mm}^{-1}, 12,448$ reflections measured, 3180 independent reflections $\left(R_{\text {int }}=0.0352\right)$. The final $R_{1}$ values were $0.0271[I>2 \sigma(I)]$. The final $w R\left(F^{2}\right)$ values were $0.0704[I>2 \sigma(I)]$. The final $R_{1}$ values were 0.0277 (all data). The final $w R\left(F^{2}\right)$ values were 0.0710 (all data). The goodness of fit on $F^{2}$ was 1.031. Flack parameter $=0.09(4)$. The crystallographic data for the structure of 3 have been deposited in the Cambridge Crystallographic Data Centre (deposition number CCDC 2118606). Copies of the data can be obtained free of charge from the CCDC via www.ccdc.cam.ac.uk.

\subsection{4 (6S,7S,8R)-2-(2-phenylethyl)-6,7,8-trihy- droxy-5,6,7,8-tetrahydrochromone (4)}

Yellow powder; $[\alpha]_{\mathrm{D}}^{27}+14.2(c=0.50, \mathrm{MeOH}) ; \mathrm{UV}$ $(\mathrm{MeOH}) \lambda_{\max }(\log \varepsilon) 372$ (2.22), 254 (4.07), 209 (4.19) $\mathrm{nm} ; \mathrm{ECD}(c \quad 0.0072, \mathrm{MeOH}) \lambda_{\max }(\Delta \varepsilon) 233(-3.14)$ $\mathrm{nm} ;{ }^{1} \mathrm{H}$ NMR and ${ }^{13} \mathrm{C}$ NMR data see Table 2; ESIMS (positive) $m / z \quad 302[\mathrm{M}+\mathrm{Na}]^{+}, \quad 627 \quad\left[\begin{array}{ll}2 & \mathrm{M}+\mathrm{Na}\end{array}\right]^{+}$;
HRESIMS (positive) $m / z 325.1046[\mathrm{M}+\mathrm{Na}]^{+}$(calcd for $\left.\mathrm{C}_{17} \mathrm{H}_{18} \mathrm{NaO}_{5}, 325.1052\right)$.

\subsection{5 (5S,6R,7S,8R)-2-(2-phenylethyl)-5,6,7-trihy- droxy-5,6,7,8-tetrahydro-8- [2-(2-phenylethyl)-7-meth- oxychromonyl-6-oxy]chromone (5)}

Yellow powder; $[\alpha]_{\mathrm{D}}^{20}+98.6(c=0.10, \mathrm{MeOH}) ; \mathrm{UV}$ $(\mathrm{MeOH}) \lambda_{\max }(\log \varepsilon) 314$ (4.29), 237 (4.85), 204 (5.02) $\mathrm{nm}$; ECD (c 0.0041, MeOH) $\lambda_{\max }(\Delta \varepsilon) 320(+5.57), 280$ (-3.87), 249 (+9.33), 229 (-1.47), $207(-20.23) \mathrm{nm}$; IR $v_{\max }(\mathrm{KBr}) 3387,1657,1603,1504,1453,1384,1271$, 1216, 1197, 1101, 1080, 998, 957, 847, 749, $700 \mathrm{~cm}^{-1} ;{ }^{1} \mathrm{H}$ NMR and ${ }^{13} \mathrm{C}$ NMR data see Table 3; ESIMS (positive) $m / z 619[\mathrm{M}+\mathrm{Na}]^{+}$; HRESIMS (positive) $m / z 619.1939$ $[\mathrm{M}+\mathrm{Na}]^{+}\left(\right.$calcd $\left.\mathrm{C}_{35} \mathrm{H}_{32} \mathrm{NaO}_{9}, 619.1944\right)$.

\subsection{6 (4S,5S,7S, 8S, 10S, 13R)-7,8, 13-trihydroxyro- tunda-1,11-dien-3-one (6)}

Pale yellow oil; $[\alpha]_{\mathrm{D}}^{27}-95.4 \quad(c=0.50, \mathrm{MeOH}) ; \mathrm{UV}$ $(\mathrm{MeOH}) \lambda_{\max }(\log \varepsilon) 234$ (4.12) (3.81) nm; ECD (c $0.015, \mathrm{MeOH}) \lambda_{\max }(\Delta \varepsilon) 246(+2.59), 203(-13.63)$ $\mathrm{nm}$; IR $v_{\max }(\mathrm{KBr}) 3416,2962,2932,2872,1686$, $1683,1600,1456,1384,1281,1196,1082,1044$, 1025, 997, $930 \mathrm{~cm}^{-1} ;{ }^{1} \mathrm{H}$ NMR and ${ }^{13} \mathrm{C}$ NMR data see Table 4; ESIMS (negative) $m / z 299[\mathrm{M}+\mathrm{Cl}]^{-}, 309$ $\left[\mathrm{M}+\mathrm{HCOO}^{-}\right]^{+}$; ESIMS (positive) $m / z 287[\mathrm{M}+\mathrm{Na}]^{+}$, $551[2 \mathrm{M}+\mathrm{Na}]^{+}$; HRESIMS (positive) $\mathrm{m} / z 287.1255$ $[\mathrm{M}+\mathrm{Na}]^{+}$(calcd for $\mathrm{C}_{15} \mathrm{H}_{20} \mathrm{NaO}_{4}, 287.1259$ ).

\subsection{7 (4S,5S,7S,8S, 10S, 13S)-7,8, 13-trihydroxyro- tunda-1,11-dien-3-one (7)}

Pale yellow oil; $[\alpha]_{\mathrm{D}}^{27}-87.1(c=0.09, \mathrm{MeOH}) ; \mathrm{UV}$ $(\mathrm{MeOH}) \lambda_{\max }(\log \varepsilon) 236$ (4.02) nm; ECD (c 0.018, $\mathrm{MeOH}) \lambda_{\max }(\Delta \varepsilon) 258(+0.52), 222(-6.96) \mathrm{nm}$; IR $v_{\max }(\mathrm{KBr}) 3425,2964,2927,2874,2852,1688,1633$, 1597, 1456, 1384, 1284, 1188, 1073, 1055, 1028, 982, $928 \mathrm{~cm}^{-1} ;{ }^{1} \mathrm{H}$ NMR and ${ }^{13} \mathrm{C}$ NMR data see Table 4; ESIMS (positive) $m / z 287[\mathrm{M}+\mathrm{Na}]^{+}, 551[2 \mathrm{M}+\mathrm{Na}]^{+}$; HRESIMS (positive) $\mathrm{m} / z 287.1253[\mathrm{M}+\mathrm{Na}]^{+}$(calcd for $\left.\mathrm{C}_{15} \mathrm{H}_{20} \mathrm{NaO}_{4}, 287.1259\right)$.

\subsection{8 (4R,5S,7S, 8S, 10S, 13S)-7,8, 13-trihydroxyro- tunda-1,11-dien-3-one (8)}

Pale yellow oil; $[\alpha]_{\mathrm{D}}^{25}-13.3(c=0.05, \mathrm{MeOH})$; UV $(\mathrm{MeOH}) \lambda_{\max }(\log \varepsilon) 235$ (4.01) nm; ECD (c 0.015, $\mathrm{MeOH}) \lambda_{\max }(\Delta \varepsilon) 223(-6.08) \mathrm{nm} ;{ }^{1} \mathrm{H}$ NMR and ${ }^{13} \mathrm{C}$ NMR data see Table 4; ESIMS (positive) $m / z 287$ $[\mathrm{M}+\mathrm{Na}]^{+}, 551[2 \mathrm{M}+\mathrm{Na}]^{+}$; EIMS $m / z$ (rel. int.) 264 $[\mathrm{M}]^{+}$(30), 246 (15), 179 (47), 136 (77), 91 (68), 55 (90), 43 (100); HREIMS $m / z 264.1359$ [M] $^{+}$(calcd for $\left.\mathrm{C}_{15} \mathrm{H}_{20} \mathrm{O}_{4}, 264.1362\right)$. 


\subsubsection{Agarotetrol (9)}

White solid; $[\alpha]_{\mathrm{D}}^{18}-17.9(c=0.20, \mathrm{MeOH}) ;{ }^{1} \mathrm{H}$ NMR (methanol- $\left.d_{4}, 500 \mathrm{MHz}\right) \delta 7.26\left(2 \mathrm{H}, \mathrm{m}, \mathrm{H}-3^{\prime}, 5\right), 7.22$ $\left(2 \mathrm{H}, \mathrm{m}, \mathrm{H}-2^{\prime}, 6^{\prime}\right), 7.18\left(1 \mathrm{H}, \mathrm{m}, \mathrm{H}-4^{\prime}\right), 6.12(1 \mathrm{H}, \mathrm{s}, \mathrm{H}-3)$, $4.74(1 \mathrm{H}, \mathrm{d}, J=4.0 \mathrm{~Hz}, \mathrm{H}-5), 4.57(1 \mathrm{H}, \mathrm{d}, J=7.5 \mathrm{~Hz}$, $\mathrm{H}-8), 4.04(1 \mathrm{H}, \mathrm{dd}, J=7.5,2.3 \mathrm{~Hz}, \mathrm{H}-7), 4.02(1 \mathrm{H}$, $\mathrm{dd}, J=4.0,2.3 \mathrm{~Hz}, \mathrm{H}-6), 3.03(2 \mathrm{H}, \mathrm{dd}, J=7.7,7.3 \mathrm{~Hz}$, $\left.\mathrm{H}_{2}-7\right)$, $2.93\left(2 \mathrm{H}, \mathrm{m}, \mathrm{H}_{2}-8^{\prime}\right) ;{ }^{13} \mathrm{C}$ NMR (methanol- $d_{4}$, $126 \mathrm{MHz}) \delta 182.0(\mathrm{C}-4), 171.2(\mathrm{C}-2), 165.4(\mathrm{C}-8 \mathrm{a})$, $141.2\left(\mathrm{C}-1^{\prime}\right), 129.6\left(\mathrm{C}-3^{\prime}, 5^{\prime}\right), 129.5\left(\mathrm{C}-2^{\prime}, 6^{\prime}\right), 127.5\left(\mathrm{C}-4^{\prime}\right)$, 121.8 (C-4a), 114.1 (C-3), 74.0 (C-6), 72.4 (C-7), 70.1 (C-8), 66.7 (C-5), $36.3\left(\mathrm{C}-8^{\prime}\right), 33.7$ (C-7'); ESIMS (positive) $m / z 341[\mathrm{M}+\mathrm{Na}]^{+}, 659[2 \mathrm{M}+\mathrm{Na}]^{+}$.

\subsubsection{4'-Methoxyagarotetrol (11)}

Light yellow solid; $[\alpha]_{\mathrm{D}}^{24}-18.3 \quad(c=0.10, \quad \mathrm{MeOH})$; ${ }^{1} \mathrm{H}$ NMR (methanol- $\left.d_{4}, 500 \mathrm{MHz}\right) \delta 7.13(2 \mathrm{H}$, br d, $\left.J=8.6 \mathrm{~Hz}, \mathrm{H}-2^{\prime}, 6^{\prime}\right), 6.82\left(2 \mathrm{H}\right.$, br d, $\left.J=8.6 \mathrm{~Hz}, \mathrm{H}-3^{\prime}, 5^{\prime}\right)$, $6.10(1 \mathrm{H}, \mathrm{s}, \mathrm{H}-3), 4.74(1 \mathrm{H}, \mathrm{d}, J=4.0 \mathrm{~Hz}, \mathrm{H}-5), 4.56(1 \mathrm{H}$, $\mathrm{d}, J=7.5 \mathrm{~Hz}, \mathrm{H}-8), 4.04(1 \mathrm{H}, \mathrm{dd}, J=7.5,2.3 \mathrm{~Hz}, \mathrm{H}-7), 4.01$ $(1 \mathrm{H}, \mathrm{dd}, J=4.0,2.3 \mathrm{~Hz}, \mathrm{H}-6), 3.74\left(3 \mathrm{H}, \mathrm{s}, 4^{\prime}-\mathrm{OMe}\right), 2.89$ $\left(2 \mathrm{H}, \mathrm{m}, \mathrm{H}_{2}-8\right), 2.97\left(2 \mathrm{H}, \mathrm{m}, \mathrm{H}_{2}-7\right)$; ${ }^{13} \mathrm{C}$ NMR (methanol$\left.d_{4}, 126 \mathrm{MHz}\right) \delta 182.0(\mathrm{C}-4), 171.4(\mathrm{C}-2), 165.4(\mathrm{C}-8 \mathrm{a})$, 159.8 (C-4), 133.1 (C-1), $130.4\left(\mathrm{C}-2^{\prime}, 6\right), 121.7$ (C-4a), 115.0 (C-3',5), 114.1 (C-3), 74.0 (C-6), 72.4 (C-7), 70.1 (C-8), 66.7 (C-5), 55.6 (4'-OMe), 36.5 (C-8), 32.9 (C-7); ESIMS (positive) $m / z 371[\mathrm{M}+\mathrm{Na}]^{+}, 719[2 \mathrm{M}+\mathrm{Na}]^{+}$; HRESIMS (positive) $\mathrm{m} / z 371.1100[\mathrm{M}+\mathrm{Na}]^{+}$(calcd for $\left.\mathrm{C}_{18} \mathrm{H}_{20} \mathrm{NaO}_{7}, 371.1107\right)$.

\subsubsection{2'-Hydroxyagarotetrol (13)}

Light yellow solid; $[\alpha]_{\mathrm{D}}^{28}-8.3(c=0.18, \mathrm{MeOH}) ;{ }^{1} \mathrm{H}$ NMR (methanol- $\left.d_{4}, 500 \mathrm{MHz}\right) \delta 7.05(1 \mathrm{H}, \mathrm{dd}, J=7.4,1.6 \mathrm{~Hz}$, H-6), $7.01(1 \mathrm{H}$, ddd, $J=8.0,7.4,1.6 \mathrm{~Hz}, \mathrm{H}-4), 6.74(1 \mathrm{H}$, br d, $J=8.0 \mathrm{~Hz}, \mathrm{H}-3), 6.72(1 \mathrm{H}$, ddd, $J=7.4,7.4,1.2 \mathrm{~Hz}$, $\mathrm{H}-5), 6.10(1 \mathrm{H}, \mathrm{s}, \mathrm{H}-3), 4.74(1 \mathrm{H}, \mathrm{d}, J=4.0 \mathrm{~Hz}, \mathrm{H}-5), 4.56$ $(1 \mathrm{H}, \mathrm{d}, J=7.4 \mathrm{~Hz}, \mathrm{H}-8), 4.04(1 \mathrm{H}, \mathrm{dd}, J=7.4,2.3 \mathrm{~Hz}, \mathrm{H}-7)$, $4.02(1 \mathrm{H}, \mathrm{dd}, J=4.0,2.3 \mathrm{~Hz}, \mathrm{H}-6), 3.00\left(2 \mathrm{H}, \mathrm{m}, \mathrm{H}_{2}-7^{\prime}\right)$, $2.92\left(2 \mathrm{H}, \mathrm{m}, \mathrm{H}_{2}-8\right) ;{ }^{13} \mathrm{C}$ NMR (methanol- $d_{4}, 126 \mathrm{MHz}$ ) $\delta 182.1(\mathrm{C}-4), 172.0(\mathrm{C}-2), 165.4$ (C-8a), 156.5 (C-2), 131.2 (C-6), 128.7 (C-4), 127.3 (C-1), 121.6 (C-4a), 120.6 (C-5), 115.9 (C-3), 113.8 (C-3), 74.0 (C-6), 72.5 (C-7), 70.1 (C-8), 66.7 (C-5), 34.7 (C-8), 29.0 (C-7); ESIMS (positive) $\mathrm{m} / z 357[\mathrm{M}+\mathrm{Na}]^{+}, 691[2 \mathrm{M}+\mathrm{Na}]^{+}$.

\subsubsection{2 (5S,6R,7R,8S)-2-(2-Phenylethyl)-5,6,7-trihy- droxy-5,6,7,8-tetrahydro-8- [2-(2-phenylethyl) chromonyl-6-oxy]chromone (19)}

Yellow powder; $[\alpha]_{\mathrm{D}}^{24}-75.8(c=0.38, \mathrm{MeOH}) ;{ }^{1} \mathrm{H}$ NMR (methanol- $\left.d_{4}, 500 \mathrm{MHz}\right)$ Unit A $\delta 7.15\left(2 \mathrm{H}, \mathrm{m}, \mathrm{H}-3^{\prime}, 5^{\prime}\right)$, $7.10(1 \mathrm{H}, \mathrm{m}, \mathrm{H}-4), 6.92\left(2 \mathrm{H}, \mathrm{m}, \mathrm{H}-2^{\prime}, 6\right), 6.15(1 \mathrm{H}, \mathrm{s}$,
$\mathrm{H}-3), 5.46(1 \mathrm{H}, \mathrm{d}, J=7.7 \mathrm{~Hz}, \mathrm{H}-8), 4.80(1 \mathrm{H}, \mathrm{d}, J=3.7 \mathrm{~Hz}$, $\mathrm{H}-5), 4.38(1 \mathrm{H}, \mathrm{dd}, J=7.7,2.3 \mathrm{~Hz}, \mathrm{H}-7), 4.10(1 \mathrm{H}, \mathrm{dd}$, $J=3.7,2.3 \mathrm{~Hz}, \mathrm{H}-6), 2.71\left(2 \mathrm{H}, \mathrm{m}, \mathrm{H}_{2}-8\right), 2.62(2 \mathrm{H}, \mathrm{m}$, $\left.\mathrm{H}_{2}-7\right)$; Unit B $\delta 7.89(1 \mathrm{H}, \mathrm{d}, J=2.5 \mathrm{~Hz}, \mathrm{H}-5), 7.62(1 \mathrm{H}$, $\mathrm{dd}, J=9.2,2.5 \mathrm{~Hz}, \mathrm{H}-7), 7.60(1 \mathrm{H}, \mathrm{d}, J=9.2 \mathrm{~Hz}, \mathrm{H}-8), 7.24$ (2H, m, H-3',5), $7.22\left(2 \mathrm{H}, \mathrm{m}, \mathrm{H}-2^{\prime}, 6^{\prime}\right), 7.16(1 \mathrm{H}, \mathrm{m}, \mathrm{H}-4)$, $6.16(1 \mathrm{H}, \mathrm{s}, \mathrm{H}-3), 3.08\left(2 \mathrm{H}, \mathrm{m}, \mathrm{H}_{2}-7\right), 3.03\left(2 \mathrm{H}, \mathrm{m}, \mathrm{H}_{2}-8\right)$; ${ }^{13} \mathrm{C}$ NMR (methanol- $d_{4}, 126 \mathrm{MHz}$ ) Unit A $\delta 181.5$ (C-4), 170.9 (C-2), 162.8 (C-8a), 140.9 (C-1), $129.4\left(\mathrm{C}-3^{\prime}, 5\right)$, 129.2 (C-2',6), 127.4 (C-4), 122.7 (C-4a), 114.5 (C-3), 78.2 (C-8), 74.5 (C-6), 70.8 (C-7), 66.3 (C-5), 36.2 (C-8), 33.5 (C-7); Unit B $\delta 180.2$ (C-4), 171.6 (C-2), 158.6 (C-6), 153.4 (C-8a), $141.2\left(\mathrm{C}-1^{\prime}\right), 129.6\left(\mathrm{C}-3^{\prime}, 5^{\prime}\right), 129.5\left(\mathrm{C}-2^{\prime}, 6^{\prime}\right)$, $127.5\left(\mathrm{C}-4^{\prime}\right), 126.2$ (C-7), 125.0 (C-4a), 120.8 (C-8), 110.4 (C-5), 110.1 (C-3), 37.0 (C-8), 34.0 (C-7); ESIMS (positive) $m / z 589[\mathrm{M}+\mathrm{Na}]^{+}$; HRESIMS (positive) $\mathrm{m} / z$ $589.1831[\mathrm{M}+\mathrm{Na}]^{+}\left(\right.$calcd for $\left.\mathrm{C}_{34} \mathrm{H}_{30} \mathrm{NaO}_{8}, 589.1838\right)$.

\subsubsection{3 (5S,6R,7S,8R)-2-(2-phenylethyl)-5,6,7-trihy- droxy-5,6,7,8-tetrahydro-8-[2-(2-phenylethyl) chromonyl-6-oxy]chromone (20)}

Yellow powder; $[\alpha]_{\mathrm{D}}^{23}+22.5(c=0.23, \mathrm{MeOH}) ; \mathrm{ECD}(c$ $0.01, \mathrm{MeOH}) \lambda_{\max }(\Delta \varepsilon) 243(+8.07), 216(-8.85) \mathrm{nm}$; ESIMS (positive) $m / z 567[\mathrm{M}+\mathrm{H}]^{+}$; HRESIMS (positive) $m / z 589.1833[\mathrm{M}+\mathrm{Na}]^{+}\left(\right.$calcd $\left.\mathrm{C}_{34} \mathrm{H}_{30} \mathrm{NaO}_{8}, 589.1838\right)$.

\subsubsection{4 (-)-Aquisinenone G (21)}

Yellow powder; $[\alpha]_{\mathrm{D}}^{20}-26.8 \quad(c=0.22, \mathrm{MeOH}) ; \mathrm{UV}$ $(\mathrm{MeOH}) \lambda_{\max }(\log \varepsilon) 314$ (3.99), 229 (4.58) nm; ECD $(c$ 0.007, MeOH) $\lambda_{\max }(\Delta \varepsilon) 313(-1.36), 277(+4.38), 249$ (-5.58), $221(-7.71), 205(+8.69) \mathrm{nm} ;{ }^{1} \mathrm{H}$ NMR (methanol- $\left.d_{4}, 500 \mathrm{MHz}\right)$ Unit A $\delta 7.16(1 \mathrm{H}, \mathrm{m}, \mathrm{H}-4), 7.08(2 \mathrm{H}$, m, H-3',5), $6.95\left(2 \mathrm{H}, \mathrm{m}, \mathrm{H}-2^{\prime}, 6^{\prime}\right), 6.03(1 \mathrm{H}, \mathrm{s}, \mathrm{H}-3), 5.52$ $(1 \mathrm{H}, \mathrm{dd}, J=3.0,2.0 \mathrm{~Hz}, \mathrm{H}-5), 4.77(1 \mathrm{H}, \mathrm{m}, \mathrm{H}-7), 4.59(1 \mathrm{H}$, $\mathrm{dd}, J=3.3,3.0 \mathrm{~Hz}, \mathrm{H}-6), 4.45(1 \mathrm{H}, \mathrm{br} \mathrm{s}, \mathrm{H}-8), 2.86(2 \mathrm{H}, \mathrm{m}$, $\left.\mathrm{H}_{2}-7\right), 2.80\left(2 \mathrm{H}, \mathrm{m}, \mathrm{H}_{2}-8\right)$; Unit B $\delta 7.67(1 \mathrm{H}, \mathrm{s}, \mathrm{H}-5), 7.23$ (2H, m, H-3',5), $7.20\left(2 \mathrm{H}, \mathrm{m}, \mathrm{H}-2^{\prime}, 6^{\prime}\right), 7.06\left(1 \mathrm{H}, \mathrm{m}, \mathrm{H}-4{ }^{\prime}\right)$, $6.89(1 \mathrm{H}, \mathrm{s}, \mathrm{H}-8), 6.12(1 \mathrm{H}, \mathrm{s}, \mathrm{H}-3), 3.02\left(2 \mathrm{H}, \mathrm{m}, \mathrm{H}_{2}-7\right)$, $2.96\left(2 \mathrm{H}, \mathrm{m}, \mathrm{H}_{2}-8\right) ;{ }^{13} \mathrm{C}$ NMR (methanol- $d_{4}, 126 \mathrm{MHz}$ ) Unit A $\delta 179.8$ (C-4), 171.5 (C-2), 166.0 (C-8a), 140.8 (C-1), $129.4\left(\mathrm{C}-2^{\prime}, 3^{\prime}, 5^{\prime}, 6^{\prime}\right), 127.5(\mathrm{C}-4), 117.4(\mathrm{C}-4 \mathrm{a})$, 114.5 (C-3), 79.3 (C-7), 72.6 (C-5), 69.7 (C-6), 66.8 (C-8), 36.1 (C-8), 33.6 (C-7); Unit B $\delta 179.5$ (C-4), 171.6 (C-2), 155.0 (C-8a), 154.5 (C-7), 147.0 (C-6), 141.2 (C-1), 129.6 (C-3',5), 129.3 (C-2',6), 127.3 (C-4), 120.9 (C-4a), 119.1 (C-5), 112.5 (C-8), 110.2 (C-3), 36.9 (C-8), 33.9 (C-7); ESIMS (positive) $m / z 587[\mathrm{M}+\mathrm{Na}]^{+}$.

\subsection{Computational methods}

Theoretical calculations of ECD spectra for compounds 6-8 were performed with the Gaussian 16 program 
package [21]. The preliminary conformational distribution search was performed by Tripos sybyl- $\times 2$ software [22]. Selected conformers with distributions higher than $1 \%$ were further optimized by the DFT method at the B3LYP/6-311 g (d) level in the Gaussian 16 program package. The ECD of the conformer of selected conformers was then calculated by the TDDFT method at the CAM-B3LYP/tzvp levels with the PCM model in methanol solution. The overall calculated ECD curves were weighted by Boltzmann distribution. The calculated ECD spectra were produced by SpecDis 1.71 [23]. Detailed calculated parameters are provided in the Additional file 1.

3.6 Corticosterone-induced damage in PC12 cellular assay The method for bioassay testing was carried out according to our previously published papers $[5,6]$.

\section{Conclusion}

Five new 2-(2-phenylethyl)chromone derivatives, three new sesquiterpenoids, and 14 known compounds were isolated from the resinous heartwood of Aquilaria sinensis. The neuroprotective activities of these isolates were evaluated using an in vitro model of PC12 cell injury induced by corticosterone. $\quad(6 S, 7 S, 8 R)$-2-(2-Phenylethyl)-6,7,8-trihydroxy-5,6,7,8-tetrahydrochromone (4), $(4 S, 5 S, 7 S, 8 S$, $10 S, 13 R)-7,8,13$-trihydroxyrotunda-1,11-dien-3-one (6), agarotetrol (9), and 6-hydroxy-2-(2-phenylethyl) chromone (17) showed the most protective activities against corticosterone-induced PC12 cell injury at concentrations from 5 to $40 \mu \mathrm{M}(P<0.001)$.

\section{Supplementary Information}

The online version contains supplementary material available at https://doi. org/10.1007/s13659-022-00326-3.

Additional file 1. Chemical structures of known compounds (9-22), key 2D NMR correlations of agarotetrol (9), general experimental procedures, computational methods for ECD of compounds $\mathbf{6 - 8}$, and NMR, HRMS, and ECD spectra of compounds $\mathbf{1 - 8}$

\section{Acknowledgements}

This study was supported by Beijing Sino-Science Aquilaria Technology Co., Ltd., Beijing, China (no. KET202101).

\section{Authors' contributions}

All authors read and approved the final manuscript.

\section{Declarations}

\section{Competing interests}

The authors declare that there are no conflicts of interest associated with this work.

\section{Author details}

${ }^{1}$ Key Laboratory of Economic Plants and Biotechnology, Yunnan Key Laboratory for Wild Plant Resources, and State Key Laboratory of Phytochemistry and Plant Resources in West China, Kunming Institute of Botany, Chinese Academy of Sciences, Kunming 650201, People's Republic of China. ${ }^{2}$ Key Laboratory of Chemistry for Natural Products of Guizhou Province, Chinese Academy of Sciences, Guiyang 550014, People's Republic of China. ${ }^{3}$ Faculty of Plant Protection, Yunnan Agricultural University, Kunming 650201, People's Republic of China.

Received: 21 December 2021 Accepted: 9 January 2022

Published online: 28 January 2022

\section{References}

1. Editorial Board of Chinese Pharmacopoeia. Chinese Pharmacopoeia, vol. 1. Beijing: China Medical Science Press; 2020. p. 192-3.

2. Su J, Liu Z, Li R-C, Yang X-J. Literature research of traditional Chinese medicine prescription containing agilawood. China J Tradit Chin Med Pharm. 2017;32:1853-5.

3. Peng D, Wang C, Liu Y, Wei J. Research progress on the chemical constituents of Aquilariae Lignum Resinatum and their pharmacological activities. Chin J Mod Appl Pharm. 2021;38:358-65.

4. Gonçalves S, Mansinhos I, Romano A. Aromatic plants: a source of compounds with antioxidant and neuroprotective effects. In: Martin CR, Preedy VR, editors. Oxidative stress and dietary antioxidants in neurological diseases. Amsterdam: Elsevier; 2020. p. 155-73.

5. Wei S-Y, Hu D-B, Xia M-Y, Luo J-F, Yan H, Yang J-H, Wang Y-S, Wang $\mathrm{Y}-\mathrm{H}$. Sesquiterpenoids and 2-(2-phenylethyl)chromone derivatives from the resinous heartwood of Aquilaria sinensis. Nat Prod Bioprosp. 2021;11:545-55.

6. He Q, Hu D-B, Zhang L, Xia M-Y, Yan H, Li X-N, Luo J-F, Wang Y-S, Yang $\mathrm{J}-\mathrm{H}$, Wang $\mathrm{Y}-\mathrm{H}$. Neuroprotective compounds from the resinous heartwood of Aquilaria sinensis. Phytochemistry. 2021;181:112554.

7. Yoshii E, Koizumi T, Oribe T, Takeuchi F, Kubo K. The structure of agarotetrol, a novel highly oxygenated chromone from agarwood (jinko) Tetrahedron Lett. 1978:19:3921-4.

8. Shimada Y, Konishi T, Kiyosawa S, Nishi M, Miyahara K, Kawasaki T. Studies on the agalwood (Jinko). IV. Structures of 2-(2-phenylethyl) chromone derivatives, agarotetrol and isoagarotetrol. Chem Pharm Bull. 1986:34:2766-73.

9. Sugiyama T, Narukawa Y, Shibata S, Masui R, Kiuchi F. Three new 5,6,7,8-tetrahydroxy-5,6,7,8-tetrahydrochromone derivatives enantiomeric to agarotetrol from agarwood. J Nat Med. 2018;72:667-74.

10. Konishi T, Sugimoto A, Kiyosawa S, Fujiwara Y. Studies on the agalwood "Jinko". XII. Structures of pentahydroxy-2-(2-phenylethy)chromone derivatives. Chem Pharm Bull. 1992;40:778-9.

11. Xiang P, Mei W, Chen H, Kong F, Wang H, Liao G, Zhou L, Dai H. Four new bi-phenylethylchromones from artificial agarwood. Fitoterapia. 2017:120:61-6.

12. Zheng K-M, Zhang J-Q, Shen P-N, Zhuo C. Preparative isolation and purification of agarotetrol and 4'-methoxyagarotetrol from Aquilaria sinensis (Lour.) Gilg by high-speed counter-current chromatography. Chin Tradit Pat Med. 2011:33:96-9.

13. Konishi T, Iwagoe K, Sugimoto A, Kiyosawa S, Fujiwara Y, Shimada Y. Studies on agalwood (Jinko). X. Structures of 2-(2-phenylethyl)chromone derivatives. Chem Pharm Bull. 1991;39:207-9.

14. Iwagoe K, Kakae T, Konishi T, Kiyosawa S, Fujiwara Y, Shimada Y, Miyahara K, Kawasaki T. Studies on the agalwood (Jinko). VIII. Structures of bi-phenylethylchromone derivatives. Chem Pharm Bull. 1989;37:124-8.

15. Huo H-X, Zhu Z-X, Song Y-L, Shi S-P, Sun J, Sun H, Zhao Y-F, Zheng J, Ferreira D, Zjawiony JK, Tu P-F, Li J. Anti-inflammatory dimeric 
2-(2-phenylethyl)chromones from the resinous wood of Aquilaria sinensis. J Nat Prod. 2017;81:543-53.

16. Shimada Y, Konishi T, Kiyosawa S. Studies on the agalwood (Jinko). VI. Structures of three 2-(2-phenylethyl)-5,6,7,8-tetrahydrochromone derivatives, AH1A, AH2a and AH2b. Chem Pharm Bull. 1986;34:3033-7.

17. Yagura T, Ito M, Kiuchi F, Honda G, Shimada Y. Four new 2-(2-phenylethyl)chromone derivatives from withered wood of Aquilaria sinensis. Chem Pharm Bull. 2003;51:560-4.

18. Yang JS, Wang YL, Su YL. Studies on the chemical constituents of Aquilaria sinensis (Lour.) Gilg. V.: isolation and characterization of three 2-(2-phenylethyl)chromone derivatives. Acta Pharm Sin. 1989;24:678-83.

19. Iwagoe K, Konishi T, Kiyosawa S, Shimada Y, Miyahara K, Kawasaki T. The structures of $\mathrm{AH}_{10}$ and $\mathrm{AH}_{11}$, nobel bi-phenylethylchromones from agalwood. Chem Pharm Bull. 1986;34:4889-91.

20. Kitajima J, Ishikawa T, Tanaka Y, Ono M, Ito Y, Nohara T. Water-soluble constituents of fennel. V. Glycosides of aromatic compounds. Chem Pharm Bull. 1998;46:1587-90

21. Gaussian 16 Citation, http://gaussian.com/citation/ (accessed on December 17, 2021)

22. SYBYL-X 2.1.1, Tripos International, 1699 South Hanley Rd., St. Louis, Missouri, 63144, USA

23. Bruhn T, Schaumlöffel A, Hemberger Y, Pecitelli G. SpecDis version 1.71, Berlin, Germany, 2017. http://specdis-software.jimdo.com.

\section{Publisher's Note}

Springer Nature remains neutral with regard to jurisdictional claims in published maps and institutional affiliations.

\section{Submit your manuscript to a SpringerOpen ${ }^{\odot}$ journal and benefit from:}

- Convenient online submission

- Rigorous peer review

- Open access: articles freely available online

- High visibility within the field

- Retaining the copyright to your article

Submit your next manuscript at $\boldsymbol{\nabla}$ springeropen.com 